\title{
Sequence Stratigraphy and Evolution of a Progradational, Foreland Carbonate Ramp, Lower Mississippian Mission Canyon Formation and Stratigraphic Equivalents, Montana and Idaho
}

\author{
S. K. Reid \\ Department of Physical Sciences \\ Morehead State University \\ Morehead, Kentucky, U.S.A. \\ S. L. Dorobek \\ Department of Geology \\ Texas A\&M University \\ College Station, Texas, U.S.A.
}

Figure 10 is in the OVERSIZE directoryffolder.

\begin{abstract}
The Lower Mississippian Mission Canyon Formation and stratigraphic equivalents in Montana and Idaho were deposited on a progradational carbonate ramp that developed on the foreland side of the Antler foredeep. Shallow subtidal and peritidal lithofacies were deposited in ramp-interior settings across most of Montana. The ramp to basin transition in westernmost Montana was a relatively narrow belt of stacked skeletal grainstone banks. Farther west, skeletal grainstone banks prograded over and interfingered with outer ramp/slope cherty limestones. In east-central Idaho, coeval lower slope and basinal strata consisted of silty to argillaceous, spicular limestones, spiculites, and spicular calcareous siltstones/fine-grained sandstones.

In individual outcrops, stacked parasequence sets are the most prominent sequence stratigraphic units. Lateral lithofacies relationships across the deformed ramp to basin transition were reconstructed using regional biostratigraphic and lithostratigraphic correlations of measured sections. Depositional sequences and system tracts were identified from characteristics of bounding surfaces, stacking patterns of parasequences and parasequence sets, and lateral lithofacies relationships.

The reconstructed ramp to basin transect illustrates a progressive upward change in third-order sequence boundary type during evolution of the Mission Canyon platform. Type 2 sequence boundaries formed early in platform development, whereas type 1 sequence boundaries dominated later
\end{abstract}


platform development. Associated ramp-margin wedges thicken and are composed of progressively larger proportions of peritidal lithofacies upward. Compared to correlative surfaces on global onlap-offlap curves, third-order sequence boundaries that formed early in Mission Canyon platform development appear subdued, whereas those that formed later appear enhanced. Combined with subsidence analysis, these relationships suggest that gradually waning flexural subsidence and falling second-order eustatic sea level permitted higher order eustatic sea levels to fall progressively farther basinward as the Mission Canyon platform evolved. This long-term decrease in accommodation profoundly influenced progradation of the Mission Canyon platform and was a major factor in maintaining a ramplike profile across the platform to basin transition.

\section{INTRODUCTION}

Modern sequence stratigraphy has continued to evolve since Sloss et al. (1949) outlined its basic concepts (see historical perspective of Ross, 1991). The advent of high-quality seismic data changed our perspective of regional stratigraphy by revealing chronostratigraphic relationships and stratal geometries (Vail et al., 1977a,b). Concepts of seismic stratigraphy subsequently have been refined and applied to well logs, cores, and outcrops, and detailed integrated studies now are common (e.g., Wilgus et al., 1988). More recently, workers have begun to integrate models of cyclic carbonate deposition with sequence stratigraphy (e.g., Goldhammer et al., 1990, 1991; Read et al., 1991). However, it is still necessary to apply sequence stratigraphy to a wider variety of carbonate platform types, preferably from different tectonic settings.

Paleozoic strata preserve a wide assortment of platform types deposited in various tectonic settings. However, the most critical portion of these Paleozoic platforms, the platform to basin transition, typically is strongly deformed during orogenesis. In addition, seismic profiles are few and of limited use for sequence stratigraphy in these areas. Therefore, studies of Paleozoic platforms rely heavily on outcrop and/or well data and require good biostratigraphic control. Studies that have successfully applied sequence stratigraphy to outcrops across carbonate platform to basin transitions (e.g., Sarg, 1988; Franseen et al., 1989) largely have been limited to well-exposed, undeformed rocks where stratal boundaries can be traced physically through mapping or on photo mosaics. In structurally complex regions, such as the North American Cordillera, undisturbed, laterally continuous outcrops are rare and stratal boundaries cannot be traced physically over great distances.

This chapter discusses the sequence stratigraphy and evolution of an Early Mississippian carbonate ramp that developed in a foreland tectonic setting in the northern Rocky Mountains of the United States. Sequence stratigraphic units were reconstructed across the tectonically shortened ramp to basin transition using six key stratigraphic sections in southwestern Montana (Figure 1). These measured sections are from a larger data set that covers western Montana and east-central Idaho (figure 1 in Dorobek et al., 1991b; Reid, 1991; S. Reid, S. Dorobek, and T. Smith, unpublished data). A transect across the ramp to basin transition was chosen because shallow-water, ramp-interior areas often are exposed during relative sea-level falls and some strata are eroded or not deposited, while a more complete record of platform evolution is preserved in coeval, deeper water deposits.

The sequence stratigraphic analysis presented in this chapter allows interpretation of the long-term evolution of a carbonate platform that appears to be transitional between a high-energy, distally steepened ramp (after Read, 1985) and a rimmed shelf. The relative influences of foreland tectonism and eustasy on development of this ramplike platform are discussed. In addition, this chapter illustrates that parasequence sets can be used as primary units for regional sequence stratigraphic analysis of thick stratigraphic intervals $(\sim 200-500 \mathrm{~m})$ in areas where seismic data are absent (or unavailable) and outcrops or wells are widely separated. Lastly, this chapter provides a comparative framework for future sequence stratigraphic studies of other Lower Mississippian strata.

\section{REGIONAL GEOLOGY}

\section{Paleogeography}

During Early Mississippian time, a broad, shallowmarine carbonate platform occupied most of the central and western United States (Figure 2) (Sando, 1976; Gutschick et al., 1980; Gutschick and Sandberg, 


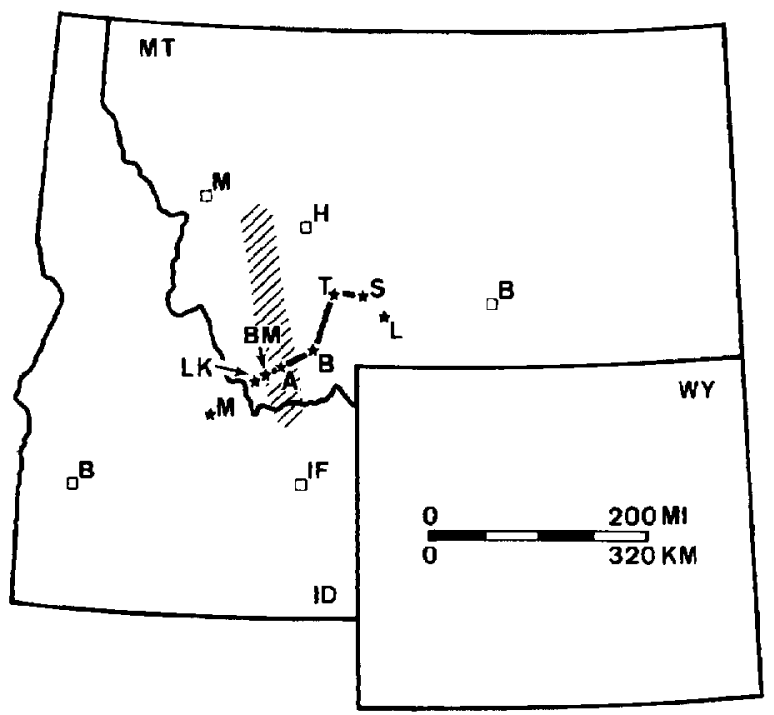

Figure 1. Locations of measured sections in southwestern Montana (stars) ( $\mathrm{A}=$ Ashbough Canyon; B = Baldy Mountain; BM = Bell/McKenzie Canyons; $\mathrm{L}=$ Livingston Canyon; $\mathrm{LK}=$ Lake Canyon; $\mathrm{M}=$ McGowan Creek; $\mathrm{S}=$ Sacajawea Peak; $\mathrm{T}=$ Trident). Hatched area is approximate position of ramp-margin skeletal banks. Bold line of section is for Figure 10. Boxes are major cities in the region [Boise (B) and Idaho Falls (IF), Idaho (ID); Missoula (M), Helena (H), and Billings (B), Montana (MT)]. Access to measured sections is summarized in Reid (1991, Appendix A).
1983; Sandberg et al., 1983). The platform surrounded isolated remnants of the Transcontinental Arch. In North Dakota and Montana, this platform extended westward from the Williston basin to the rapidly subsiding Antler foredeep along the western margin of North America (Figure 2). The axis of the foredeep, whose northern extension is preserved in east-central Idaho, was approximately $1500-1800 \mathrm{~km}$ west of the Transcontinental Arch (Gutschick and Sandberg, 1983). Both the axis of the foredeep and the transition from shallow-water platform to slope environments trended approximately north-south relative to Mississippian plate reconstructions (Figure 2). These Early Mississippian paleogeographic features are preserved in the Mission Canyon Formation and stratigraphic equivalents in Montana, Idaho, and North Dakota.

\section{Stratigraphic Framework}

Foraminifera, conodonts, and corals have been used to define biozones within Mississippian strata of the northern Rocky Mountains (Figure 3) (Sando et al., 1969; Sandberg et al., 1983; Sando, 1985; Sando and Bamber, 1985). Because all three zonations have been used to correlate these strata, this study follows the composite biozonation of Sando (1985) as a matter of convenience. Composite biochronozones range from 0.75 to 3.4 m.y., depending on the absolute time scale used to calculate durations (Sandberg and Poole, 1977; Sandberg et al., 1983; Sando, 1985). The biostratigraphic zonations shown in Figure 3 have

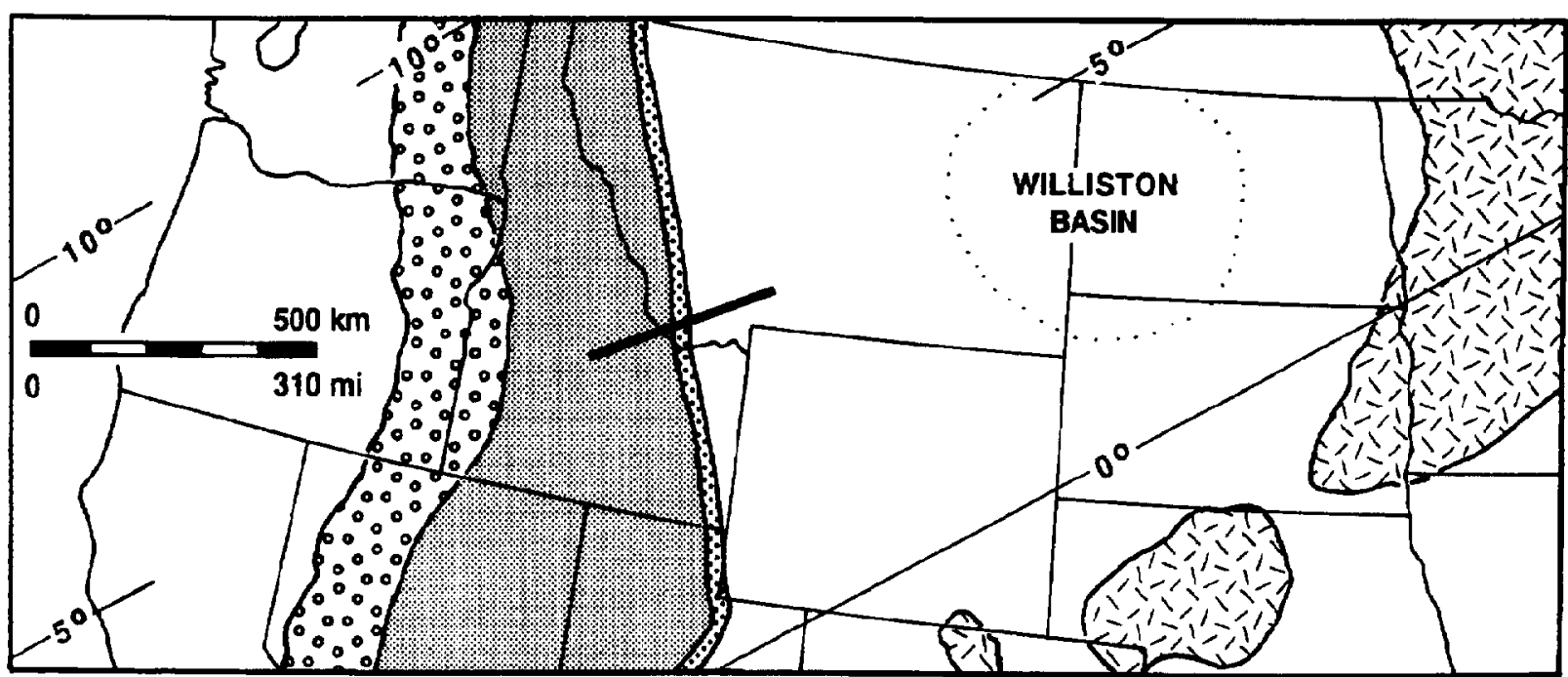

음 ANTLER OROGENIC BELT

CARBONATE PLATFORM
ANTLER FOREDEEP

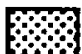

PLATFORM MARGIN

Figure 2. Early Mississippian paleogeography of the north-central and northwestern United States (after Gutschick and Sandberg, 1983). Bold line is approximate line of section for Figure 4. 


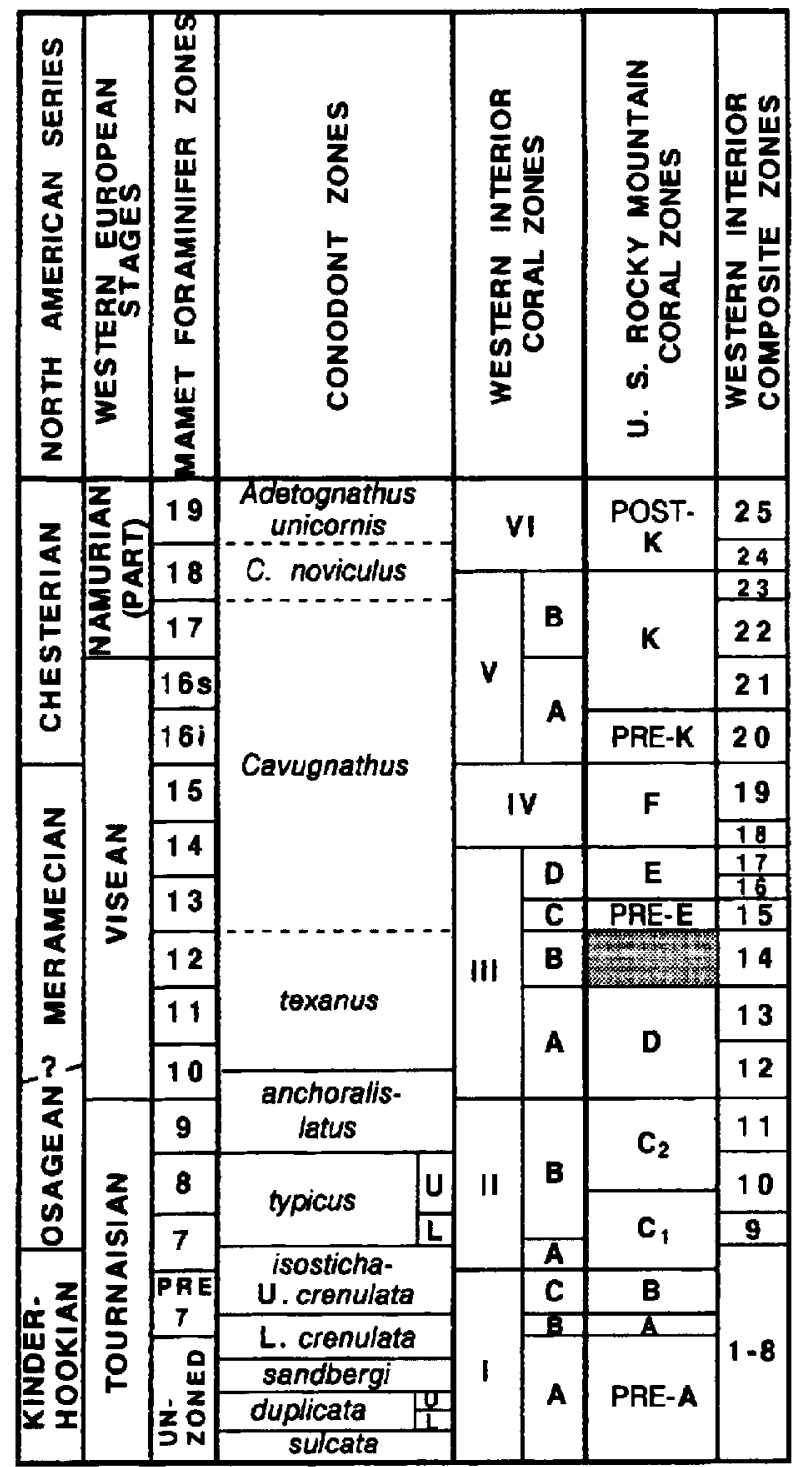

Figure 3. Biostratigraphic zonation used in the region. Compiled from Sando et al. (1969), Sando (1985), and Sando and Bamber (1985).

been used to establish regional, formation-scale correlations in Mississippian strata throughout the western interior of the United States. Published biostratigraphic data, paleontologic samples collected by the senior author, and formation-scale correlations between stratigraphic sections examined in this study are summarized in Reid (1991).

The Mission Canyon Formation (200-400 m thick) and stratigraphic equivalents conformably overlie the McGowan Creek and Lodgepole formations and predominantly consist of shallow subtidal to peritidal platform facies throughout most of Montana (Figure 4). These facies grade westward into a relatively nar- row belt of thick skeletal grainstone in westernmost Montana, which also is included in the Mission Canyon Formation (Huh, 1967, 1968; Rose, 1976; Nichols, 1980; Peterson, 1986; Reid, 1991). Near the Idaho-Montana border, grainstones of the Mission Canyon Formation interfinger with cherty limestones of the Middle Canyon Formation (Sando et al., 1985; Reid, 1991). Farther west, the upper member of the McGowan Creek Formation and the Middle Canyon Formation are correlative with the Mission Canyon Formation and consist of silty, spicular limestones, spiculites, calcareous siltstones, and fine-grained sandstones (Figure 4; Huh, 1967, 1968; Sandberg, 1975; Nilsen, 1977; Skipp et al., 1979; Gutschick and Sandberg, 1983).

The top of the Mission Canyon Formation is a regional unconformity that represents from 9 to 14 m.y. of subaerial exposure in central Montana (Figure 4) (Sando, 1976; Skipp et al., 1979; Gutschick et al., 1980; Sandberg et al., 1983; Sando, 1988). The Mission Canyon Formation was extensively karstified across most of Montana during this time (Middleton, 1961; Roberts, 1966; Sando, 1974, 1988). In westernmost Montana, however, deposition was continuous and shallow subtidal to peritidal facies of the McKenzie Canyon Formation (Figure 4) and equivalent deepwater facies of the upper Middle Canyon Formation were deposited in middle to late Meramecian time (Sando et al., 1985).

\section{Platform Model}

The Mission Canyon platform cannot be assigned to a single platform type (e.g., after Read, 1985). Previous studies have characterized the Mission Canyon platform as a ramp (sensu Ahr, 1973; Gutschick et al., 1980) and as a rimmed shelf with 200-400 m relief at its margin (Rose, 1976). A lack of balanced regional cross sections in the study area prevents accurate calculation of depositional slopes. However, the detailed stratigraphic cross section presented later in this chapter incorporates estimated palinspastic distances between measured sections (after Peterson, 1986) and suggests that depositional slopes were ramplike.

Although depositional slopes across the Mission Canyon platform appear ramplike, these slopes may not have been homoclinal. Thin, carbonate gravityflow deposits and soft sediment deformation in slope facies (folding and sedimentary boudinage structures; Reid, 1991; W. Perry, personal communication, 1989) indicate that somewhat greater depositional slopes existed west of the platform to basin transition. In addition, the Antler foredeep was starved during deposition of the Mission Canyon platform (Sandberg, 1975; Nilsen, 1977; Skipp et al., 1979; Gutschick and Sandberg, 1983), which suggests that the difference between platform and basinal sedimentation rates may have been sufficient to generate a break in slope at the platform margin. 

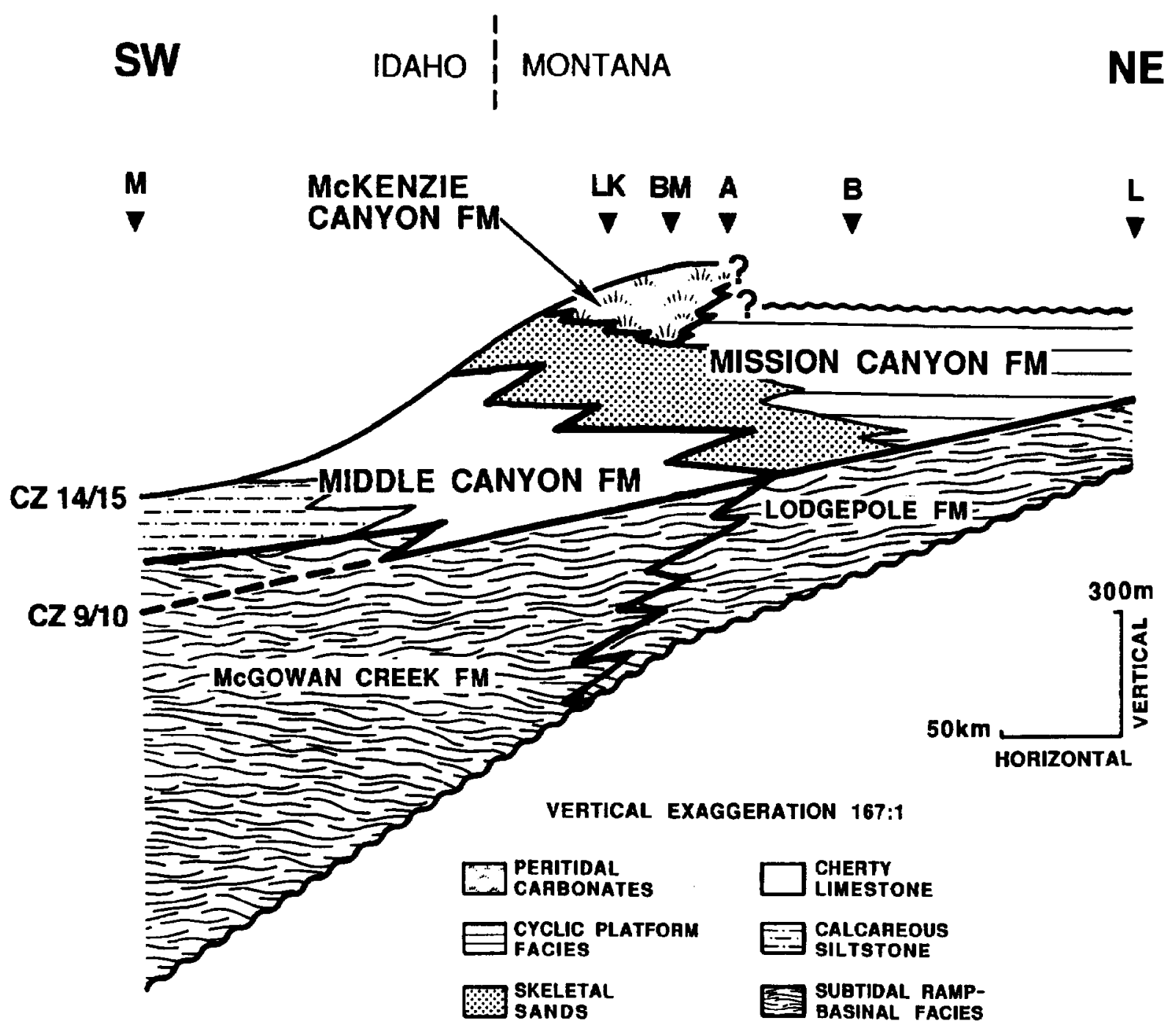

Figure 4. Highly schematic, formation-scale cross section of the Mission Canyon Formation and stratigraphic equivalents. CZ 9/10 and CZ 14/15 are composite biozone boundaries (Figure 3). Arrows indicate points of control (see Figure 1 for locations).

A reefal rim did not develop along the Mission Canyon platform margin because diverse assemblages of reef-building organisms apparently did not exist during Early Mississippian time (Heckel, 1974; James, 1984). Instead, wave-agitated skeletal banks formed a relatively narrow facies belt along the outer platform while much of the platform interior was covered by skeletal-ooid grainstone (Huh, 1968; Rose, 1976; Nichols, 1980; Peterson, 1986; Reid, 1991). The combination of ramplike slopes, widespread skeletal-ooid grainstones across the platform interior, a (subtle?) break in slope at the platform margin, and a relatively narrow skeletal grainstone belt along the platform margin suggests that the Mission Canyon platform was transitional between a high-energy, distally steeped ramp (Read, 1985) and a rimmed shelf. In this chapter, we refer to this type of carbonate platform as a "progradational carbonate ramp."

\section{LITHOFACIES AND DEPOSITIONAL ENVIRONMENTS \\ Peritidal Facies}

Peritidal facies occur throughout the Mission Canyon Formation across most of Montana. Near the Montana-Idaho border, peritidal facies are confined to the McKenzie Canyon Formation. These facies form $0.5-10 \mathrm{~m}$ thick, shallowing-upward cycles that consist of, from bottom to top: skeletal-peloid grainstone/packstone; fenestral limestone; and cryptal- 
galaminite, evaporitic carbonates, and/or solution collapse breccia (Figure 5).

\section{Skeletal-Peloid Grainstone/Packstone}

Dark brown-gray to light tan-gray, color-mottled, skeletal-peloid packstone/grainstone occurs as thick to massive beds that overlie skeletal-ooid grainstones. Current-generated sedimentary structures are absent and thin to medium interbeds of intraclast-peloid packstone/grainstone and ooid-skeletal grainstone are rare. Grain types include peloids, intraclasts, ooids, calcispheres, foraminifera, gastropods, and crinoid fragments (Figure 5A).

\section{Interpretation}

Thick, skeletal-peloid packstone/grainstone formed in shallow, relatively low-energy subtidal settings. Color mottling and the lack of current-generated sedimentary structures suggest these sediments were subjected to intense bioturbation.

\section{Fenestral Limestone}

Medium gray to light tan-gray fenestral limestone overlies skeletal-peloid grainstone/packstone. Thin interbeds of bioturbated to laminated skeletal-peloid grainstone/packstone and cryptalgalaminite are common. Fenestral limestone fabrics range from mudstone to packstone with peloids, micritized grains, calcispheres, ostracods, gastropods, calcareous algae, and coated grains as primary constituents.

Fenestral fabrics are variable. In color-mottled fenestral limestone, tubular and irregular fenestrae are common. Fenestral limestone that is not color mottled usually contains irregular to laminoid fenestrae with inclusion-rich, isopachous calcite cement and geopetal sediment (Figure 5B). Fenestral limestones with abundant micritized/coated grains typically contain irregular and sheetlike fenestrae that are filled with laminated dolomite silt. This type of fenestral limestone also has scattered evaporite pseudomorphs and may cap parasequences.

\section{Interpretation}

Most fenestral limestone was deposited in intertidal to very shallow subtidal environments (Logan, 1974; Shinn, 1983). Color mottling and some tubular fenestrae probably were produced by burrowers in very shallow subtidal environments. Inclusion-rich, isopachous cements in some fenestrae are interpreted as marine phreatic cements that also formed in shallow subtidal environments. Micritized/coated grain fenestral limestones with sheetlike fenestrae and scattered evaporite pseudomorphs may represent intertidal to supratidal facies that have been overprinted by vadose meteoric diagenesis (Fischer, 1964; Goldhammer et al., 1987; Mazzullo and Birdwell, 1989).

\section{Restricted Peritidal Facies}

Cryptalgalaminite facies caps most parasequences. This facies consists of light gray to tan, fine-crystalline dolostone, calcareous dolostone, or dolomitic lime mudstone with crinkly to irregular, millimeter-scale laminations (Figure 5C). Shallow mud cracks and centimeter-scale tepee structures are common; evaporite pseudomorphs are rare. Thin layers of laminated intraclast-peloid grainstone/packstone and fenestral limestone commonly are interbedded with cryptalgalaminite facies.

Some parasequences are capped by very thin to thin, irregularly bedded, brown-gray to yellow-tan, peloidal mudstone/packstone. Dolomitization varies from slight (scattered dolomite rhombs) to complete. Calcite pseudomorphs after gypsum and anhydrite are common and occur as 1-10 cm nodules or 0.1-1$\mathrm{cm}$-long crystal pseudomorphs that commonly form irregular rosettes (Figure 5D). Coated grains (pisoids) with circumgranular and intragranular cracks are rare (Figure 5E). Where present, evaporitic facies overlie cryptalgalaminite or laminated, peloid grainstone/packstone. However, thin beds of dolomitic sandstone (10-30 cm thick) with evaporite pseudomorphs rarely overlie evaporitic facies and may form parasequence caps.

\section{Interpretation}

Restricted peritidal facies formed in supratidal and high intertidal areas of semiarid to arid tidal flats that developed when the Mission Canyon platform aggraded to sea level (cf. modern examples from Kinsman, 1964; Kendall and Skipwith, 1969; Purser, 1973; Logan et al., 1974). Storms intermittently deposited thin sheets of laminated intraclast-peloid grainstone/packstone on the flats. Evaporitic conditions prevented burrowing organisms from destroying mechanical and algal laminations. Pisoids in evaporitic facies formed where supratidal flats were subjected to vadose marine and/or vadose meteoric diagenesis (Read, 1974; Scholle and Kinsman, 1974; Esteban, 1976; Esteban and Klappa, 1983).

\section{Solution-Collapse Breccia}

Brecciated horizons from 0.5-75 $\mathrm{m}$ thick occur in the Mission Canyon Formation across most of Montana and in the McKenzie Canyon Formation in westernmost Montana. Lateral continuity and thickness of breccia horizons is highly variable. Contacts with unbrecciated rocks are irregular; fitted fabrics with surrounding, unbrecciated rocks are common around the margins of some breccia horizons. Breccias contain clasts and tabular blocks ( $<1 \mathrm{~cm}-2 \mathrm{~m}$ long) of all peritidal lithofacies (Figure 5F); clasts of skeletal-ooid grainstone are rare. Approximate original stratigraphic position of various clast lithologies still is preserved within many breccias. For example, fenestral limestone clasts typically grade upward into breccia dominated by cryptalgalaminite clasts, which in turn grade upward into brecciated evaporitic carbonates.

\section{Interpretation}

Most solution collapse breccias formed through dissolution of evaporite horizons and carbonate lithologies during karstification of the Mission Canyon platform, especially in middle to late Mera- 

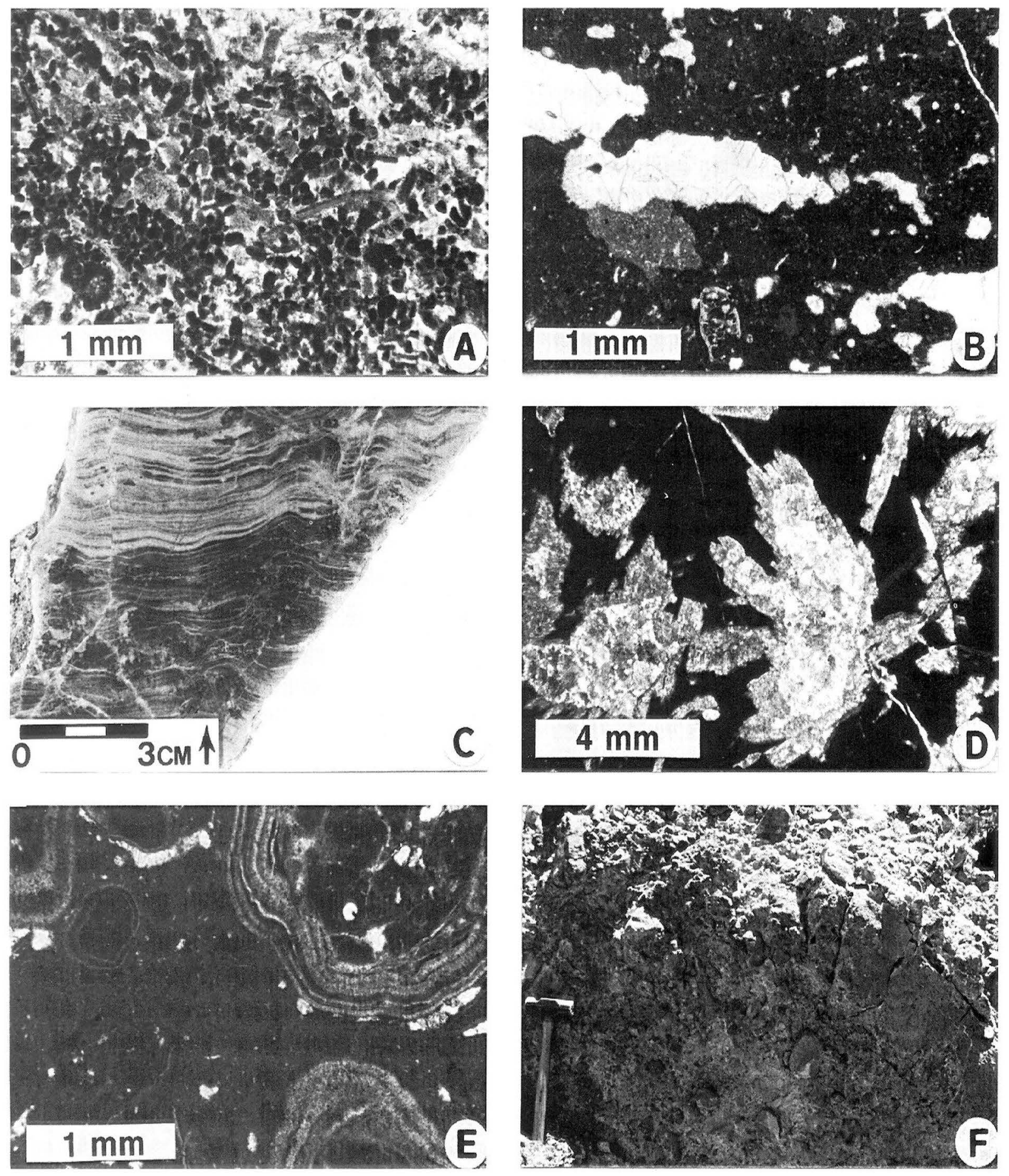

Figure 5. Peritidal facies. (A) Skeletal-peloid grainstone/packstone; (B) fenestral limestone with irregular to laminoid fenestrae; (C) slab of cryptalgalaminated dolostone, microporosity stained gray to enhance laminations; (D) evaporite pseudomorphs in restricted peritidal facies; (E) coated grains (pisoids) with circumgranular and intragranular cracks; and (F) solution collapse breccia.

mecian time when the major unconformity at the top of the Mission Canyon Formation developed (Sando, 1972, 1976, 1988). Some dissolution also probably occurred following Pennsylvanian(?) to Early Tertiary uplift of the Mission Canyon Formation.
Examination of clast lithologies, however, allows interpretation of original depositional environments. Most brecciated lithofacies originally were deposited in peritidal environments, except for rare clasts of subtidal grainstone. 


\section{Subtidal Ramp-Interior and Ramp-Margin Facies}

Skeletal-ooid grainstone is the dominant subtidal lithofacies across most of Montana and occurs as thick to massive beds in the McKenzie Canyon and Mission Canyon formations. In westernmost Montana, massive skeletal grainstones dominate the upper Middle Canyon and Mission Canyon formations.

\section{Skeletal-Ooid Grainstone}

Skeletal-ooid grainstone is medium gray to light tan-gray and contains abundant ooids and skeletal grains (Figure 6A). Peloids also are common locally. Skeletal grains are abraded, bored, and partially micritized, and include crinoids, foraminifera, calcispheres, brachiopods, ostracods, and bryozoans. Cross-bedding and ripple cross-lamination are common. Beds commonly have irregular basal contacts (up to $10 \mathrm{~cm}$ of local relief) that are overlain by intraclast/skeletal lags. Skeletal-ooid grainstone commonly overlies peloid-skeletal packstone/wackestone.

\section{Interpretation}

Common erosional basal contacts, abundant ooids, cross-bedding, and ripple cross-lamination suggest that skeletal-ooid grainstones formed in mobile sandshoal environments in shallow-water, ramp-interior settings (Ball, 1967; Hine, 1977). Shoals probably formed as laterally discontinuous barriers or isolated shoal complexes that partially protected peritidal environments. Peritidal facies accumulated adjacent to grainstone shoal complexes in quieter water and/or more restricted environments.

\section{Massive Skeletal Grainstone}

Skeletal grainstone is massively bedded and dominated by pelmatozoan grains, in contrast to skeletalooid grainstones across most of the rest of Montana. Low-angle, tabular cross-bedding and horizontal laminations are rare to common. Moderately sorted, fragmented to articulated pelmatozoans are the dominant grain type (Figure 6B). Ramose and fenestrate bryozoan debris, slightly abraded rugose corals and brachiopods, and large rugose and syringoporid coral colonies (0.5-1 m across) also are common locally. Massive skeletal grainstone typically overlies cherty, bioturbated, peloid-skeletal wackestone/packstone.

\section{Interpretation}

Massive skeletal grainstone in the Mission Canyon and upper Middle Canyon formations of western Montana were deposited in wave-agitated, skeletal bank environments along the ramp to basin transition in western Montana (cf. Laporte, 1969; Dorobek and Read, 1986). The less-fragmented, diverse fossil assemblage (including large coral colonies and articulated crinoid columnals) within these grainstones suggest approximately in situ sediment accumulation. Skeletal banks probably accumulated where dense thickets of pelmatozoans dominated benthic communities. Lime mud was not produced or was winnowed by fair-weather waves.

\section{Outer Ramp, Slope, and Basinal Facies}

Outer ramp, slope, and basinal facies become progressively richer in siliciclastics toward the axis of the Antler foredeep in east-central Idaho (Figure 4). Bioturbated cherty limestone is confined to the Middle Canyon and Mission Canyon formations of westernmost Montana and east-central Idaho. Laminated cherty limestone is confined to the Middle Canyon Formation of westernmost Montana and east-central Idaho. Mixed carbonate/siliciclastic and calcareous siltstone/sandstone facies are confined to the Middle Canyon and upper McGowan Creek formations in east-central Idaho.

\section{Peloid-Skeletal Wackestone/Packstone}

Dark brown-gray to medium gray, bioturbated, peloid-skeletal wackestone/packstone (Figure 6C) gradationally overlies bioturbated, cherty limestone and underlies massive skeletal grainstone facies and, less commonly, skeletal-ooid grainstone. Poorly sorted, whole to slightly abraded brachiopods, fenestrate bryozoans, rugose corals, and articulated crinoid stems are common. Bioturbation is moderate to intense. Irregular, bedding-parallel chert nodules and stringers (2-5 $\mathrm{cm}$ thick) are rare to common. Thin (3-10 cm thick), discontinuous beds of peloid-skeletal packstone/grainstone with irregular basal contacts (up to $2 \mathrm{~cm}$ local relief) also are common. These laterally discontinuous interbeds have coarse-grained skeletal debris at their bases, commonly fine upward, and have gently undulatory to horizontal laminations. Upper parts of these thin interbeds may be bioturbated and grade into surrounding wackestone/ packstone facies.

\section{Interpretation}

Abundant lime mud, a diverse benthic fauna, and extensive bioturbation suggest that peloid-skeletal wackestone/packstone formed below fair-weather wave base in open-marine environments (Wilson, 1975). Thin, discontinuous packstone/grainstone interbeds probably represent storm deposits that were not destroyed by burrowing organisms (cf. Kreisa, 1981).

\section{Bioturbated Cherty Limestone}

Dark gray to dark brown-gray, bioturbated, cherty, peloid-skeletal wackestone/packstone gradationally overlies laminated cherty limestone facies and grades upward into peloid-skeletal wackestone/packstone facies. Skeletal grains include abundant sponge spicules that are mixed with fine sand-size echinoderm debris and peloids (Figure 6D). Whole rugose corals, brachiopods, and articulated crinoid stems are rare to common. Bedding in this facies is defined by very thin to medium, irregular limestone layers which alternate with thin (1-10 cm thick), discontinuous, black to dark gray chert beds and irregular, bedding-parallel chert nodules (Figure 7A). Thin- to medium-bedded, structureless layers of coarsegrained crinoid grainstone/packstone are rare. Bioturbation is slight to intense. Farther west in 

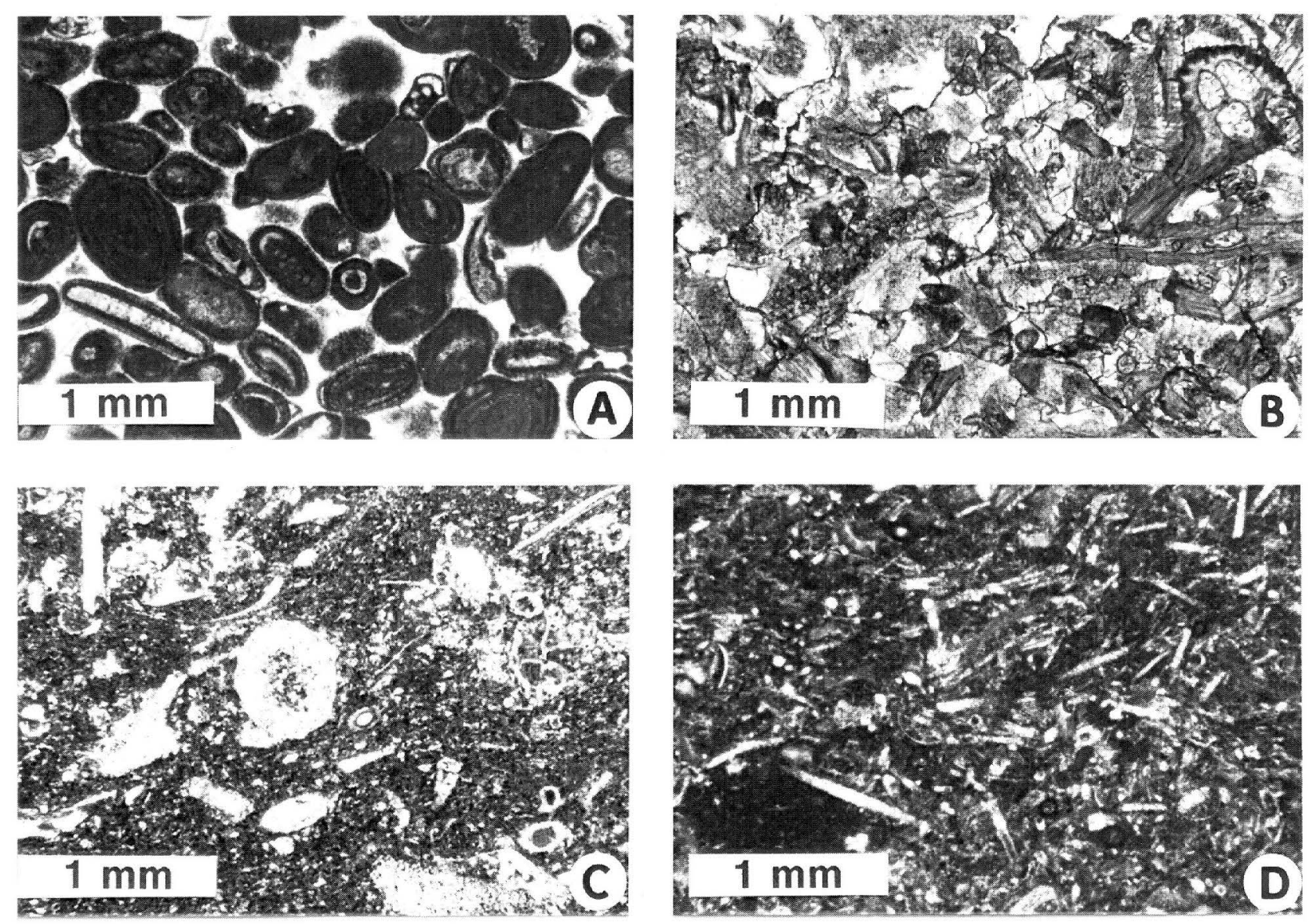

Figure 6. Subtidal platform and outer ramp-upper slope facies. (A) Skeletal-ooid grainstone; (B) skeletal grainstone; (C) peloid-skeletal wackestone/packstone; and (D) spicular peloid-skeletal packstone/wackestone.

Idaho, this facies becomes argillaceous, coarsegrained crinoid grainstone/packstone beds are absent, and black chert is rare. Instead, chert occurs as abundant, bedding-parallel incipient nodules or as silicified argillaceous seams and laminae.

\section{Interpretation}

Abundant chert and sponge spicules, a relatively low-diversity benthic fauna, and lack of preserved current-generated sedimentary structures suggest that bioturbated cherty limestone formed in outer ramp to upper slope environments below fair-weather wave base and perhaps below storm wave base (cf. Wilson, 1969; Cook and Enos, 1977). However, thinbedded storm deposits may have been destroyed by abundant burrowing infauna. Rare structureless grainstone beds may represent sediment gravity flows (debris flows? or coarse-grained turbidites) derived from updip skeletal banks (Middleton and Hampton, 1976; Davies, 1977; Lowe, 1979).

\section{Laminated Cherty Limestone}

Black to dark gray, laminated to thin, even-bedded, cherty limestone and bedded chert with very thin $(1-3 \mathrm{~cm})$ limestone interbeds typically overlies mixed carbonate/siliciclastic facies. Centimeter-thick layers to very thin beds of black, spicule-rich chert alternate with spicular, peloid-skeletal wackestone/packstone beds $(<10 \mathrm{~cm}$ thick). Skeletal-rich layers commonly fine upward and consist of finegrained sand- to silt-sized echinoderm fragments and unidentifiable skeletal debris. Macrofossils are very rare. Horizontal and wavy laminations are abundant, but ripple cross-laminations are common (Figure 7B). Slight bioturbation is rare. Some soft sediment deformation occurs locally as contorted to gently folded horizons up to $1.5 \mathrm{~m}$ thick. Layers of structureless crinoid grainstone (10-30 $\mathrm{cm}$ thick) also are rare.

\section{Interpretation}

General absence of macrofossils and bioturbation suggests that laminated cherty limestone was deposited in middle- to lower-slope environments, below storm-wave base, and perhaps below the photic zone. Dysaerobic conditions probably limited burrowing infauna, thus preserving primary sedimentary structures. Alternating layers of chert and upward-fining, laminated limestone probably were 
deposited by turbidity currents generated updip; sediments were derived from shallower slope and rampmargin areas to the east (cf. Davies, 1977). Structureless crinoid grainstone beds, similar to those in bioturbated cherty limestones, were deposited as rare sediment gravity flows (debris flows? or coarsegrained turbidites) that were derived from skeletal bank facies to the east. Contorted to gently folded horizons were produced by incipient failure and downslope movement of semicohesive slope deposits (cf. Cook and Taylor, 1977).

\section{Mixed Carbonate/Siliciclastic Facies}

Mixed carbonate/siliciclastic facies gradationally overlies calcareous siltstone/fine-grained sandstone facies. Bedding is even and very thin to thin. Internally, beds consist of graded laminae $(3 \mathrm{~mm}$ to 1 $\mathrm{cm}$ thick) of black to dark tan-gray, silty to argillaceous, pyritic, skeletal-spicule wackestone/packstone that are intercalated with millimeter-scale, horizontal to wavy laminae of siliciclastic silt and fine sand. Interlayering appears to be random. Skeletal grains consist of unidentifiable, silt-size debris and rare radiolarian tests (Figure 7C); macrofossils are very rare to absent. In westernmost measured sections, this facies primarily consists of argillaceous spiculite. Chondrites and Planolites (0.5-5 $\mathrm{mm}$ diameter) disrupt laminations locally.

\section{Interpretation}

Mixed carbonate/siliciclastic rocks formed in lower slope to basin floor environments (cf. Wilson, 1969; Cook and Enos, 1977). Graded, alternating carbonate and siliciclastic laminae may represent thin, distal turbidites that were intermittently shed from the eastern Mission Canyon platform and the western Antler highlands, respectively. Abundant pyrite and lack of macrofossils and significant bioturbation suggest that deposition occurred below the photic zone in dysaerobic conditions (Seilacher, 1967; Rhoads, 1975).

\section{Calcareous Siltstone/Sandstone}

Calcareous siltstone/sandstone consists of black to dark gray, pyritic, laminated, calcareous siltstone and less-common fine-grained sandstone. This facies underlies and grades upward into mixed carbonate/siliciclastic facies. Very thin to thin even beds contain horizontal planar laminations (Figure 7D), but wavy laminations and slight to moderate bioturbation occur locally. Individual laminae fine upward. Locally, some laminae exhibit boudinage structures or are fractured perpendicular to bedding. Sponge spicules are common; unidentifiable, very finegrained skeletal debris is rare.

\section{Interpretation}

Calcareous siltstone/sandstone probably was deposited in basin floor and lowermost slope environments. Deposition probably occurred in anaerobic(?) to dysaerobic conditions below the photic zone as indicated by abundant pyrite and a general lack of bioturbation or endemic fauna. Upward-fining laminae probably represent distal, low-density, siliciclastic turbidites that were derived from the western side of the basin (cf. Nilsen, 1977). Boudinage structures and fractured laminae probably are synsedimentary deformation features produced by downslope movement of partially lithified to well-lithified sediment. Very little platform-derived carbonate sediment reached this part of the basin during deposition of this facies.

\section{SEQUENCE STRATIGRAPHIC NOMENCLATURE}

Before discussing the vertical and lateral arrangement of the lithofacies described above, a very brief summary of basic sequence stratigraphic concepts and nomenclature is warranted. A full review of sequence stratigraphy is beyond the scope of this chapter.

It is well known that smaller scales of depositional cyclicity are superimposed on larger scales of depositional cyclicity (e.g., Goldhammer et al., 1990, 1991). Therefore, some nomenclatural hierarchy is required to distinguish the relative magnitudes (orders) of sequence stratigraphic units. In this chapter, we rank sequence stratigraphic units according to their respective distinguishing characteristics (after Sarg, 1988; Van Wagoner et al., 1988) and according to their durations (Vail et al., 1977a; Haq et al., 1988).

The smallest sequence stratigraphic unit is the parasequence, which is equivalent to the ubiquitous fifth-order (104-105 year duration), shallowingupward, depositional cycles seen throughout the sedimentary record (Sarg, 1988; Van Wagoner et al., 1988). Parasequence sets are groups or bundles of stacked parasequences bounded by major marine flooding surfaces (Van Wagoner et al., 1988). The fundamental sequence stratigraphic unit, the sequence, ranges in duration from fourth-order ( $10^{5}-10^{6}$ years) to thirdorder (106-107 years). Sequences are relatively conformable successions of genetically related strata bounded by unconformities and their correlative conformities (Mitchum, 1977; Vail et al., 1977a; Van Wagoner et al., 1988). Sequence bounding unconformities show evidence of subaerial erosional truncation (and, in some areas, correlative submarine erosion) or subaerial exposure and represent significant hiatuses (Van Wagoner et al., 1988). Internally, sequences are comprised of parasequences and parasequence sets that are arranged into systems tracts (see Sarg, 1988, and Van Wagoner et al., 1988, for explanations of systems tracts). A supersequence (second-order, $10^{7}-10^{8}$ year duration) is a stacked set of sequences bounded by major unconformities (Vail et al., 1977a; Haq et al., 1988). Stacked sets of supersequences form megasequences (first order, $>10^{8}$ year duration; Vail et al., 1977a; Haq et al., 1988). Sequences identified by Sloss (1963) are examples of supersequences and megasequences (Mitchum et al., 1977; Haq et al., 1988). 

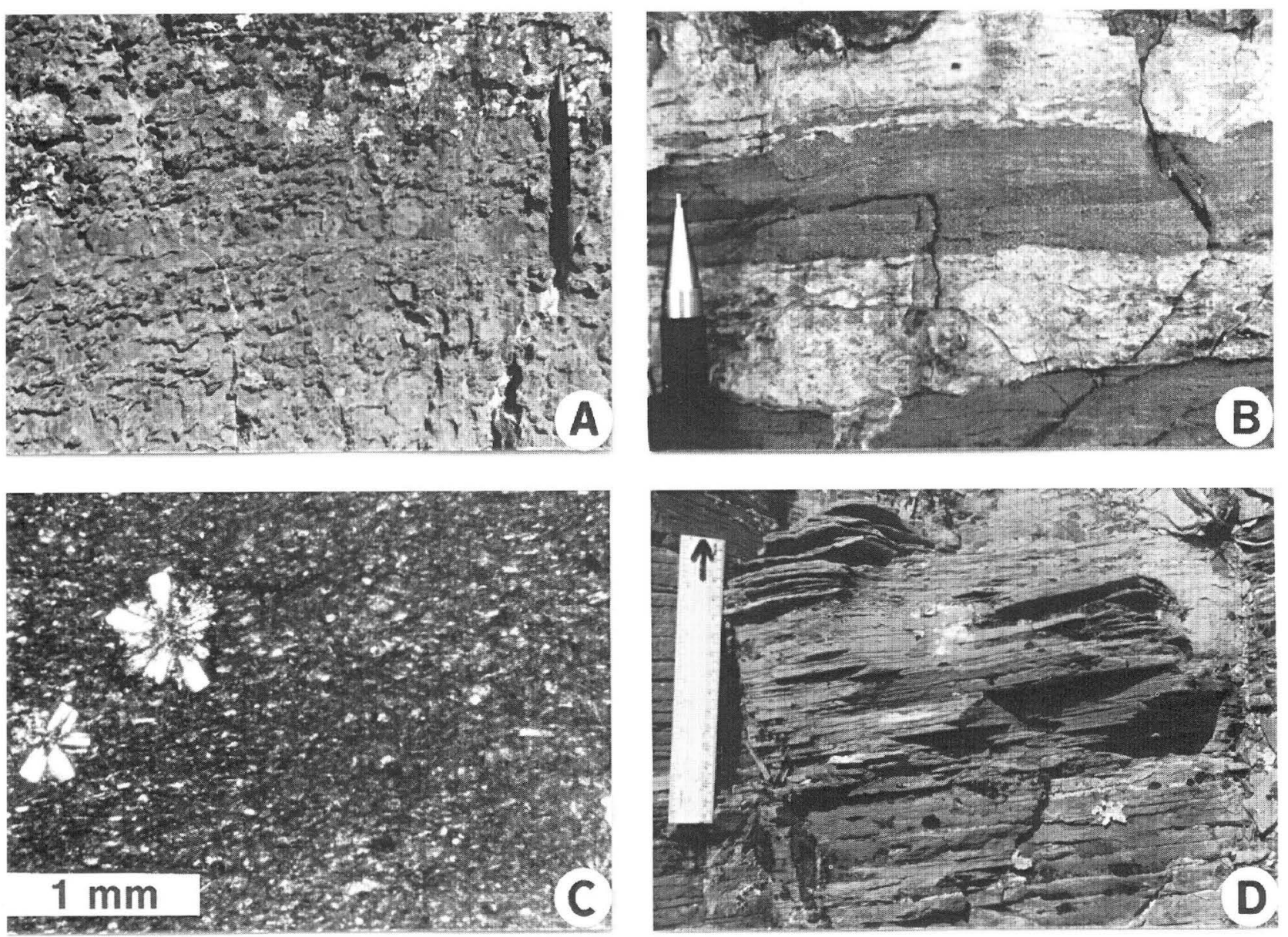

Figure 7. Slope and basinal facies. (A) Heavily bioturbated cherty limestone. Chert stands in relief. Note nearly complete destruction of layering in chert. Instead, chert follows burrows. (B) Horizontal and ripple crosslaminations in spicular peloid-skeletal packstone (turbidite). Lighter layers are weathered chert horizons. (C) Radiolarian tests and silt-size skeletal debris in mixed carbonate/siliciclastic facies. (D) Horizontal laminated calcareous siltstone/sandstone.

\section{VERTICAL LITHOFACIES RELATIONSHIPS}

Two scales of sequence stratigraphic units can be recognized based on vertical lithofacies relationships. In individual outcrops, the Mission Canyon Formation and its stratigraphic equivalents consist of prominent, 18-62-m-thick, shallowing-upward units composed of the lithofacies described previously. In shallow-water ramp-interior areas, these relatively thick intervals are comprised of stacked, smaller scale cycles; however, smaller scale cycles have not been recognized in outer ramp/slope and basinal strata. The set of lithofacies that defines larger scale, shallowing-upward units exhibits stratigraphic and paleogeographic variations.

\section{Ramp-Interior Settings}

In shallow-water, ramp-interior settings, largescale shallowing-upward units consist of, in ascend- ing order (1) peloid-skeletal wackestone/packstone; (2) skeletal-ooid grainstone; (3) skeletal-peloid grainstone/packstone; and (4) typically upward-thinning, stacked cycles of peritidal facies (Figure 8; Figure 9, upper left enlarged inset column). Thick-bedded to massive skeletal-ooid grainstone, the most common lithofacies at the bases of ramp-interior parasequence sets, appears noncyclic. All facies within this generalized set of lithofacies may not be present within individual units. Facies that cap smaller scale cycles in ramp-interior settings often show evidence of subaerial exposure such as desiccation features, evaporite pseudomorphs, and vadose diagenetic fabrics. Larger scale unit boundaries in shallow-water platform settings are placed along the highest peritidal cap that is overlain by relatively thick $(\sim 3-10 \mathrm{~m})$, subtidal facies (Figure 8). Careful observation of clast lithologies within solution collapse breccias allows some unit boundaries to be placed within brecciated horizons because overall shallowing-upward characteristics frequently are preserved within the breccias. 


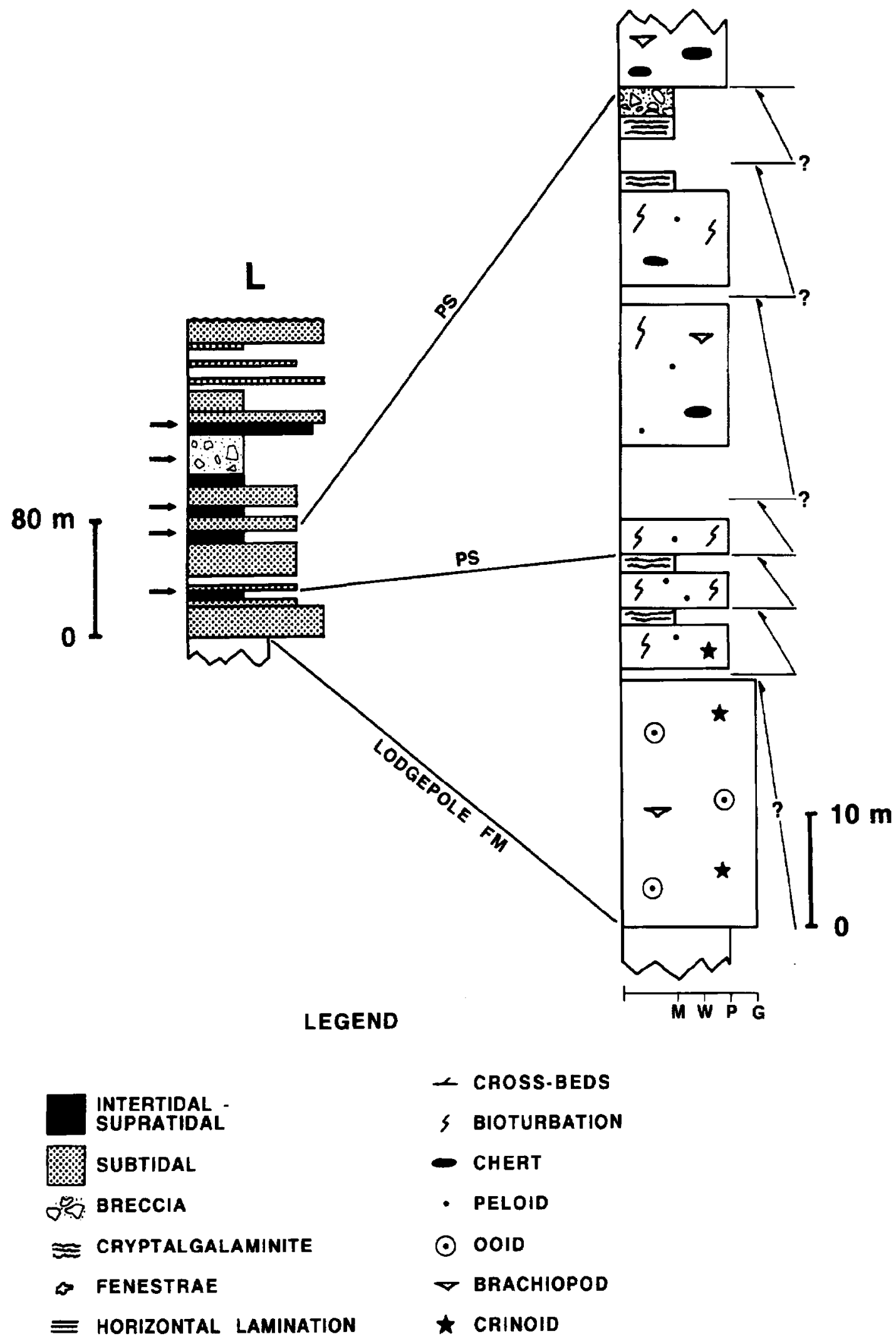

Figure 8. Typical ramp interior parasequence sets. Left column is the entire thickness of the Mission Canyon Formation at location $L$ (Figure 1). Arrows beside left column indicate parasequence set boundaries.

Enlargement of basal two parasequence sets and internal parasequences shown in right column. Lithofacies within parasequence sets are similar throughout the section (cf. Figure 10). 


\section{Outer Ramp/Slope Settings}

Larger scale, shallowing-upward units can be identified in outer ramp/slope settings but meter-scale cycles have not been recognized. Outer ramp/slope units are characterized by repeated thick intervals of bioturbated cherty limestone overlain by thick-bedded to massive skeletal grainstone (Figure 9). Units in deeper slope settings consist of thick intervals of laminated cherty limestone overlain by bioturbated cherty limestone (Figure 10, locations BM, LK). Larger scale, shallowing-upward units from outer ramp/slope environments are bounded by surfaces that separate shallower-water deposits below from thick, deeper water facies above (Figure 9).

\section{Sequence Stratigraphic Interpretation}

Approximately 1-10 m thick, shallowing-upward cycles recognized in measured sections from rampinterior settings are parasequences. The $18-62 \mathrm{~m}$ thick depositional cycles, originally interpreted by Reid (1991) and Reid and Dorobek (1991) as sequences, probably represent parasequence sets (J. Markello, personal communication, 1992). Defining boundaries are major marine flooding surfaces (sensu Van Wagoner et al., 1988). In ramp-interior settings, flooding surfaces are located at the bases of $\sim 3-10$-m-thick deeper water lithofacies that abruptly overlie peritidal carbonates (Figure 8). Parasequence set boundaries are placed at the bases of 5-50-m-thick cherty limestones that overlie massive skeletal grainstones in outer ramp/slope settings (Figure 9).

\section{Approximate Durations of Parasequence Sets}

Approximate durations of parasequence sets were calculated using the biostratigraphically best constrained measured section that likely represents essentially continuous deposition throughout Mission Canyon platform development (Figure 1, location $\mathrm{BM}$; Figure 9). Biostratigraphic boundaries near the base and top of location BM (Figures 3,9) bracket the time during which the Mission Canyon Formation and stratigraphic equivalents were deposited (Sando et al., 1985; Reid, 1991). Absolute ages of biozone boundaries were determined using the Mississippian time scales of Sandberg et al. (1983), Sando (1985), and Ross and Ross (1987). Stratigraphic equivalents of the Mission Canyon Formation at location BM were deposited over a time span of 10.9 to 12.4 m.y., depending on the time scale used.

Average durations of parasequence sets were calculated by dividing the amount of time represented by the Mission Canyon Formation and stratigraphic equivalents at location BM by the number of parasequence sets recognized in the measured section. Location BM contains at least 13 parasequence sets (Figure 9). The covered interval near the top of the section may conceal 1 or 2 additional parasequence sets. Given 13 to 15 parasequence sets deposited over a 10.9 to $12.4 \mathrm{~m} . \mathrm{y}$. period, average durations range from 727 k.y. (10.9 m.y. divided by 15) to 954 k.y. (12.4 m.y. divided by 13 ).

Approximate durations of parasequence sets also were calculated based on measured thicknesses and average accumulation rates (again using location $\mathrm{BM}$ ). A minimum average accumulation rate of 4.2 $\mathrm{cm} / \mathrm{k} . \mathrm{y}$. was calculated by dividing measured thickness $(525 \mathrm{~m})$ by 12.4 m.y. A maximum average accumulation rate of $6.3 \mathrm{~cm} / \mathrm{k} . \mathrm{y}$. was calculated by dividing a decompacted thickness of $683 \mathrm{~m}$ by 10.9 m.y. (assumes $30 \%$ decompaction throughout the section). Durations were calculated by dividing measured parasequence set thickness by minimum average accumulation rate (minimum durations) or by dividing decompacted unit thickness by maximum average accumulation rate (maximum durations). Parasequence sets range from $429 \mathrm{k}$.y. to 1.3 m.y. in duration based on these calculations. Therefore, parasequence sets appear to be fourth order (105-106 years duration). Parasequences within parasequence sets probably are fifth order $\left(10^{4}-10^{5}\right.$ years duration) and sequences (discussed below) comprised of parasequences and parasequence sets probably are third order (106-107 years duration).

\section{RECONSTRUCTION OF SEQUENCES AND SYSTEMS TRACTS}

Sequence stratigraphic analysis across the Mission Canyon ramp to basin transition is difficult. Lateral facies relationships used to define sequences and systems tracts cannot be directly observed across the Mission Canyon platform because well-exposed, undeformed outcrops of Lower Mississippian strata in the Northern Rockies are widely separated and typically located in different thrust sheets.

In our earlier attempts at sequence stratigraphic analysis of the Mission Canyon ramp to basin transition (Reid, 1991; Reid and Dorobek, 1991), we overemphasized vertical lithofacies relationships and interpreted the previously described 18-62-m-thick parasequence sets as sequences. We interpreted the highest peritidal cap at the top of each unit as a sequence boundary (i.e., an unconformity representing a "significant hiatus") because these horizons typically show evidence of subaerial exposure in ramp-interior settings. However, our regional correlations of these "sequences" (figure 6 in Reid and Dorobek, 1991) did not illustrate important internal facies geometries (i.e., systems tracts) within individual "sequences." In this chapter, we reevaluate our earlier attempts to apply sequence stratigraphic analysis to the Mission Canyon ramp to basin transition.

\section{Correlation Methods}

Regional biostratigraphic and lithostratigraphic correlations were used to reconstruct facies relationships across the deformed ramp to basin transition. Then depositional sequences and system tracts within sequences were interpreted from characteristics of 


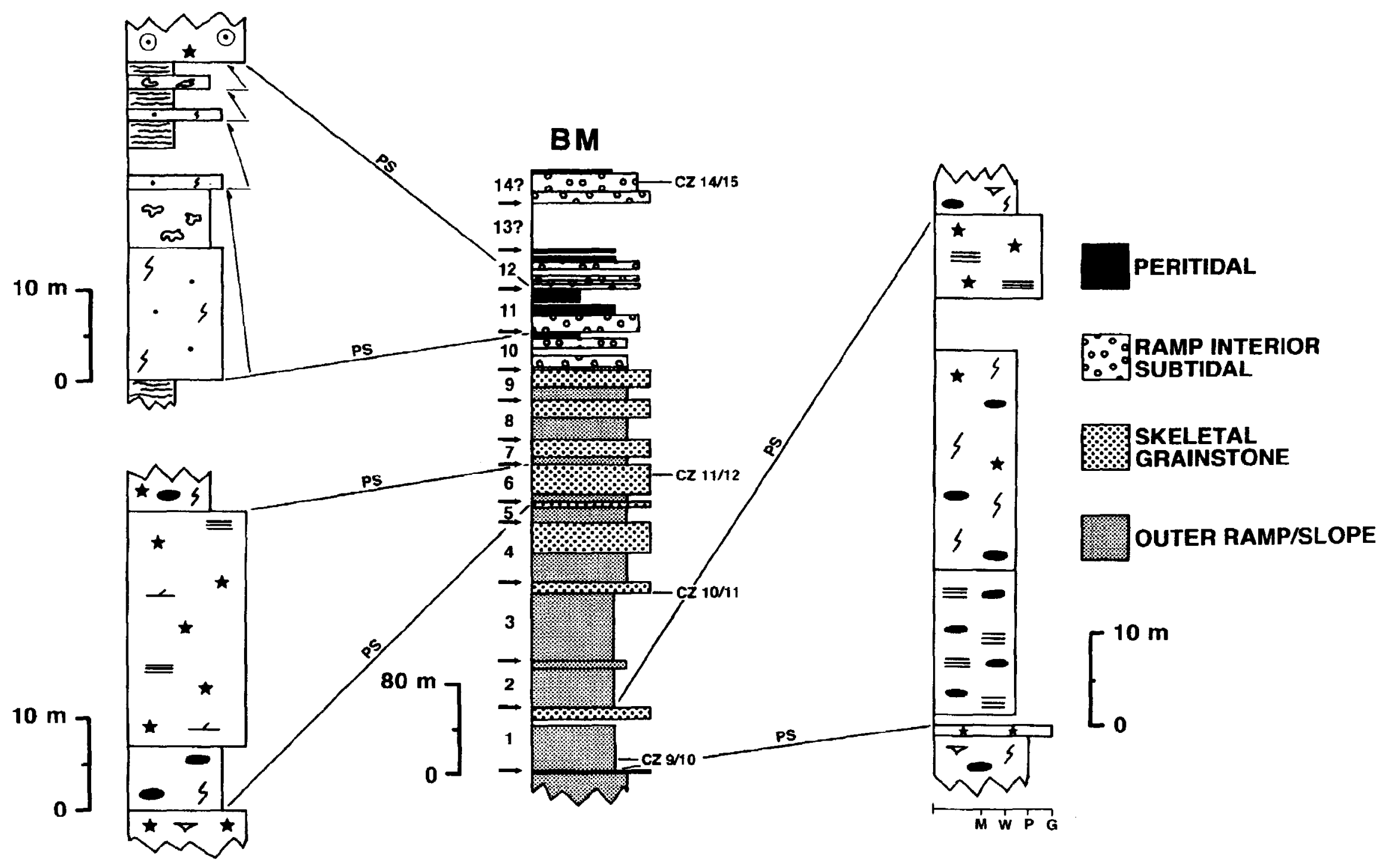


apparent bounding surfaces, stacking patterns of parasequence sets, and lateral lithofacies relationships.

Regionally extensive biozone boundaries were used to correlate six key measured sections that form a transect across the Mission Canyon ramp to basin transition (Figures 1, 3, 10). Datums are represented as basinward sloping surfaces because biostratigraphic control generally is contained in subtidal lithofacies (Gutschick et al., 1980; Sando, personal communication, 1988; Sando and Dutro, 1960, 1980; Sando et al., 1969; Sando et al., 1985; Reid, 1991) that probably dipped in a basinward direction originally.

Due to a lack of biostratigraphic control, key biozone boundaries were not recognized at two of the measured stratigraphic sections along the study transect (Figure 10, locations T, A). Location T was correlated using the thick grainstone at the base of the Mission Canyon Formation as a datum. This interval is an easily recognized and reliable regional lithologic marker that immediately overlies a known biozone boundary at other locations (Sando and Dutro, 1974; J. L. Wilson, personal communication, 1990; Reid, 1991). However, the likelihood of facies changes at and basinward of the ramp-margin precluded the use of this grainstone as a datum in more basinward settings.

Location A was included in the key transect because it is critically located near the ramp margin; however, the section is incomplete and lacks biostratigraphic control. The datum used to correlate this section is a prominent major marine flooding surface that can be recognized across southwestern Montana. At location LK, this surface is expressed as the contact between thick $(30 \mathrm{~m})$ skeletal grainstones, just above the center of the measured section, and overlying thick $(28 \mathrm{~m}$ ) cherty limestones (Figure 10$)$. At location A, this major marine flooding surface probably coincides with the base of thick skeletal grainstones that overlie thick peritidal lithofacies just above the center of the measured section (Figure 10). The exceptionally thick $(75 \mathrm{~m})$ breccia at the top of location A contains clasts of mixed lithology that prevented the identification of sequence stratigraphic units in this interval.

\section{Identification of Sequences}

Figure 10 is an attempt at sequence stratigraphic analysis across the reconstructed Mission Canyon ramp to basin transition. Across the ramp-interior, sequence boundaries should be expressed as uncon- formities and therefore are placed at horizons that appear to have experienced longer term subaerial exposure than that indicated at the tops of most parasequence sets. The major unconformity at the top of the Mission Canyon Formation and two stratigraphically lower breccia horizons are regionally correlatable (Figure 10; S. Dorobek, T. Smith, S. Reid, unpublished data; Sando, 1972, 1974, 1976, 1988) and are interpreted as sequence boundaries in ramp-interior settings. More localized breccias probably formed later during development of the major unconformity above the Mission Canyon Formation and during Pennsylvanian(?) to early Tertiary uplift of Mississippian strata (Sando, 1972, 1974, 1976, 1988).

Sequence boundaries should become conformable in more basinward settings. Therefore, sequence boundaries and transgressive flooding surfaces in outer ramp/slope settings are identified based on anomalous facies changes where Walther's Law of adjacent versus vertical facies relations appears to be violated. Sequence boundaries are placed at the bases of thick skeletal and skeletal-ooid grainstones that abruptly overlie cherty limestones (outer ramp/slope lithofacies) in the most basinward locations (Figure 10, locations BM, LK). Similarly, sequence boundaries in ramp-margin settings are placed at the bases of shallow subtidal to peritidal lithofacies that abruptly overlie outer ramp/slope or ramp-margin lithofacies (Figure 10, location A).

The uppermost sequence boundary can be recognized only basinward of the inferred ramp-margin (Figure 10, locations A, BM). This sequence boundary tentatively is placed at the base of the largely siliciclastic Kibbey Formation (not examined in this study), which conformably (Sando et al., 1985) overlies the McKenzie Canyon Formation (tops of locations $\mathrm{A}, \mathrm{BM}, \mathrm{LK}$ ). The contact between the Mission Canyon and Kibbey formations defines the major regional unconformity across the rest of Montana (Figure 4). Cratonward increase in the duration of this major unconformity suggests that the Kibbey Formation onlapped the exposed Mission Canyon platform in middle to late Meramecian time (Sando, 1976; Skipp et al., 1979; Gutschick et al., 1980; Sandberg et al., 1983; Sando, 1988).

\section{Identification of Systems Tracts}

Systems tracts are identified based on position within sequences, relations to bounding surfaces, and

Figure 9. Parasequence sets from outer ramp/slope setting. Center column is entire thickness of Middle Canyon, Mission Canyon, and McKenzie Canyon formations at location BM (Figure 1). Arrows to left of column indicate boundaries of parasequence sets. Enlargements of specific parasequence sets shown on left and right. Parasequences are not recognized in outer ramp or slope lithofacies. Parasequence sets are numbered for comparison with Williston basin subintervals (Figures 13, 14). CZ 9/10, CZ 10/11, CZ 11/12, and CZ 14/15 are composite biozone boundaries (Figure 3). Note appearance of progressively shallower water lithofacies in stratigraphically higher parasequence sets suggesting long-term progradation. Lithologic symbols as in Figure 8. 
lithofacies within constituent parasequences and parasequence sets (Sarg, 1988; Van Wagoner et al., 1988). However, systems tracts are difficult to recognize using widely spaced outcrops, particularly in ramp-interior settings where regional correlation of parasequences and parasequence sets may be complicated by erosion at sequence and parasequence boundaries and by possible shingling of depositional cycles (Read et al., 1991).

Identification of systems tracts across the Mission Canyon ramp interior is interpretive and largely based on vertical stacking patterns. Vertical parasequence stacking patterns within ramp-interior parasequence sets are progradational (Figures 8, 9, upper left enlarged inset column) while vertical stacking patterns of ramp-interior parasequence sets appear largely aggradational (Figure 10). Therefore, sequences in ramp-interior settings appear to consist primarily of highstand systems tracts dominated by skeletal-ooid grainstone ("keep-up" highstand systems tracts of Sarg, 1988). However, basal parts of sequences may be transgressive systems tracts that display progradational parasequence stacking within parasequence sets ("keep-up" transgressive systems tracts of Sarg, 1988).

In ramp-margin and outer ramp/slope settings, identification of systems tracts is more straightforward. Measured sections are more closely spaced, stacking patterns of parasequence sets are more obvious, and bounding surfaces are better expressed (Figure 10). Identification and deposition of deeper water systems tracts is discussed in more detail later.

\section{CAUSAL MECHANISMS}

Our basic approach to determine possible causal mechanisms for depositional cyclicity in the Mission Canyon Formation and stratigraphic equivalents has been to compare sequence stratigraphic analysis with quantitative subsidence analyses (Dorobek et al., 1991a,b; Reid, 1991), published Carboniferous onlapofflap curves (Ross and Ross, 1987; Reid, 1991; Reid and Dorobek, 1991), and correlative strata in the Williston basin (Reid, 1991; Reid and Dorobek, 1991). The following brief summary of this previous work incorporates our revised sequence stratigraphic analysis (Figure 10); however, our primary conclusions about causal mechanisms still seem valid.

\section{Biostratigraphic Dating of Sequence Boundaries}

Sequence boundaries are dated using existing biostratigraphic control (summarized by Reid, 1991). Ages are assigned based on proximity of sequence boundaries to biozone boundaries, preferably using outer ramp/slope sections where sequence boundaries are more conformable. $\mathrm{SB}_{2}(\mathrm{~A})$ is approximately equivalent to the composite zone $10 / 11$ boundary (Figures 3,10 , locations $\mathrm{BM}, \mathrm{S}$ ). $\mathrm{SB}_{2}(\mathrm{~B})$ is approximately equivalent in age to the composite zone 11/12 boundary (Figures 3,10 , locations $\mathrm{LK}, \mathrm{BM}, \mathrm{S}$ ). $\mathrm{SB}_{1}(\mathrm{~A})$ cannot be dated in outer ramp/slope sections because of poor biostratigraphic control. However, the age of this surface may be approximately equivalent to the composite zone $13 / 14$ boundary, the youngest biozone boundary recognized below the major regional unconformity overlying the Mission Canyon Formation (Figures 3, 10) (Sando, 1976, 1985; Gutschick et al., 1980). $\mathrm{SB}_{1}(\mathrm{~B})$ approximately coincides with the composite zone 14/15 boundary (Figures 3, 9, 10, location BM).

\section{Subsidence History}

Figure 11 is a subsidence analysis of section $\mathrm{S}$ (Figures 1, 10), one of six measured sections we have analyzed across the Antler foreland in Idaho and Montana (Dorobek et al., 1991a,b; Reid, 1991). These curves have been corrected to reflect only tectonic subsidence and eustasy (i.e., relative sea-level changes or accommodation; see methods in Dorobek et al., 1991a; Reid, 1991). All curves are similar in form and contain three Mississippian segments (Figure 11).

Tectonic subsidence probably was the dominant component of Mississippian accommodation events (Dorobek et al., 1991a,b; Reid, 1991). The steep Kinderhookian to early Osagean segment, represented by onlapping strata of the Lodgepole and lower McGowan Creek formations (Figure 4), is interpreted as a period of rapid tectonic subsidence concurrent with eustatic sea-level rise (Figures 11, 12). Subsidence slowed dramatically during Osagean to middle Meramecian time when the Mission Canyon Formation and stratigraphic equivalents were deposited (Figure 11). Tectonic subsidence decreased during this time but must have slightly outpaced coeval second-order eustatic sea-level fall until middle to late Meramecian time (cf. Figures 11, 12). From middle to late Meramecian time to at least the end of the Mississippian period, tectonic subsidence increased and was augmented by eustatic sea-level rise. Onlap of the major regional unconformity at the top of the Mission Canyon Formation occurred during this final Mississippian accommodation event (Figures 11, 12).

\section{Comparison with Global Onlap-Offlap Curve}

All sequence boundaries recognized in this study correlate with third-order sequence boundaries on the global onlap-offlap curve of Ross and Ross (1987) (Figure 12). Our interpretations of sequence boundary types do not always agree with those of Ross and Ross (1987) (cf. Figures 10, 12). In addition, we could not identify a sequence boundary in our study area that corresponds with the sequence boundary near the composite zone 12/13 biozone boundary (Figure 12). We attribute these discrepancies to local variations in tectonic subsidence (discussed in more detail later). 
SACAJAWEA PEAK, MT

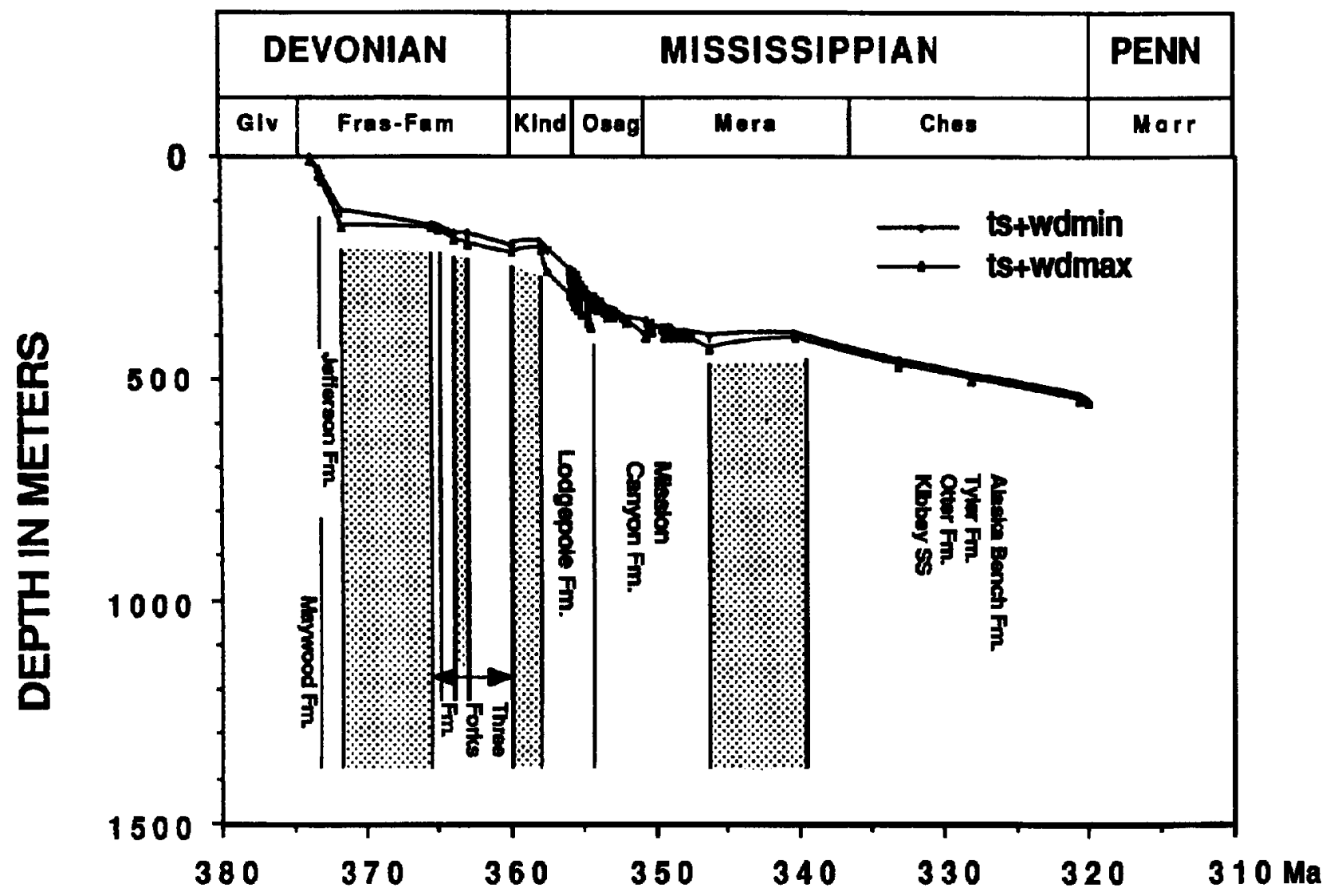

Figure 11. Subsidence analysis of section S (from Dorobek et al., 1991a,b; Reid, 1991). Stippled areas are unconformities. Note three Mississippian segments of the curve. The Mission Canyon Formation and stratigraphic equivalents were deposited during slow Osagean to middle Meramecian subsidence.

\section{Correlations with Williston Basin Strata}

In previous papers, we attempted to correlate parasequence sets in our most basinward measured sections (Figures 9, 10, locations LK, BM) with informal subintervals of the Mission Canyon and Charles formations in the central Williston basin (Figure 13) (Reid, 1991; Reid and Dorobek, 1991). Subintervals are $\sim 10-40$-m-thick, shallowing-upward units comprised of smaller scale cycles that generally contain, in ascending order (1) skeletal-ooid grainstone; (2) ooid-pisoid grainstone; (3) peloidal, pisoid grainstone/packstone; (4) cryptalgalaminite and evaporitic dolostone; (5) anhydrite and cryptalgalaminite; and (6) siliciclastics and mixed dolostone, siliciclastics, and anhydrite (Harrison and Flood, 1956; Harris et al., 1966; Hendricks, 1988; Petty, 1988). The datum used for these lithostratigraphic correlations was the composite zone $11 / 12$ boundary, the only reliable biostratigraphic marker that can be used to correlate between southwestern Montana and the Williston basin (Figures 3, 10,13) (Waters and Sando, 1987; published and new biostratigraphic data summarized in Reid, 1991; Reid and Dorobek, 1991).

Correlations of parasequence sets in southwestern Montana with subintervals in the Williston basin illustrate several similarities between the two areas. The number of parasequence sets $(>13)$ is similar to the number of subintervals (15) (Figures 9, 13, 14; numbers may be equivalent but covered intervals at locations LK and BM may conceal 2 parasequence sets). General vertical stacking patterns of parasequence sets and subintervals also are similar (Figures $9,13,14)$. In addition, the lowest maximum flooding surface and the maximum flooding surface above $\mathrm{SB}_{2}(\mathrm{~B})$ appear to correlate with "transgressive discontinuities" that separate the Tilston and FrobisherAlida intervals and the Rival and Midale subintervals, respectively (Figures 10,13,14) (Petty, 1988; Reid, 1991; Reid and Dorobek, 1991). These sim- 


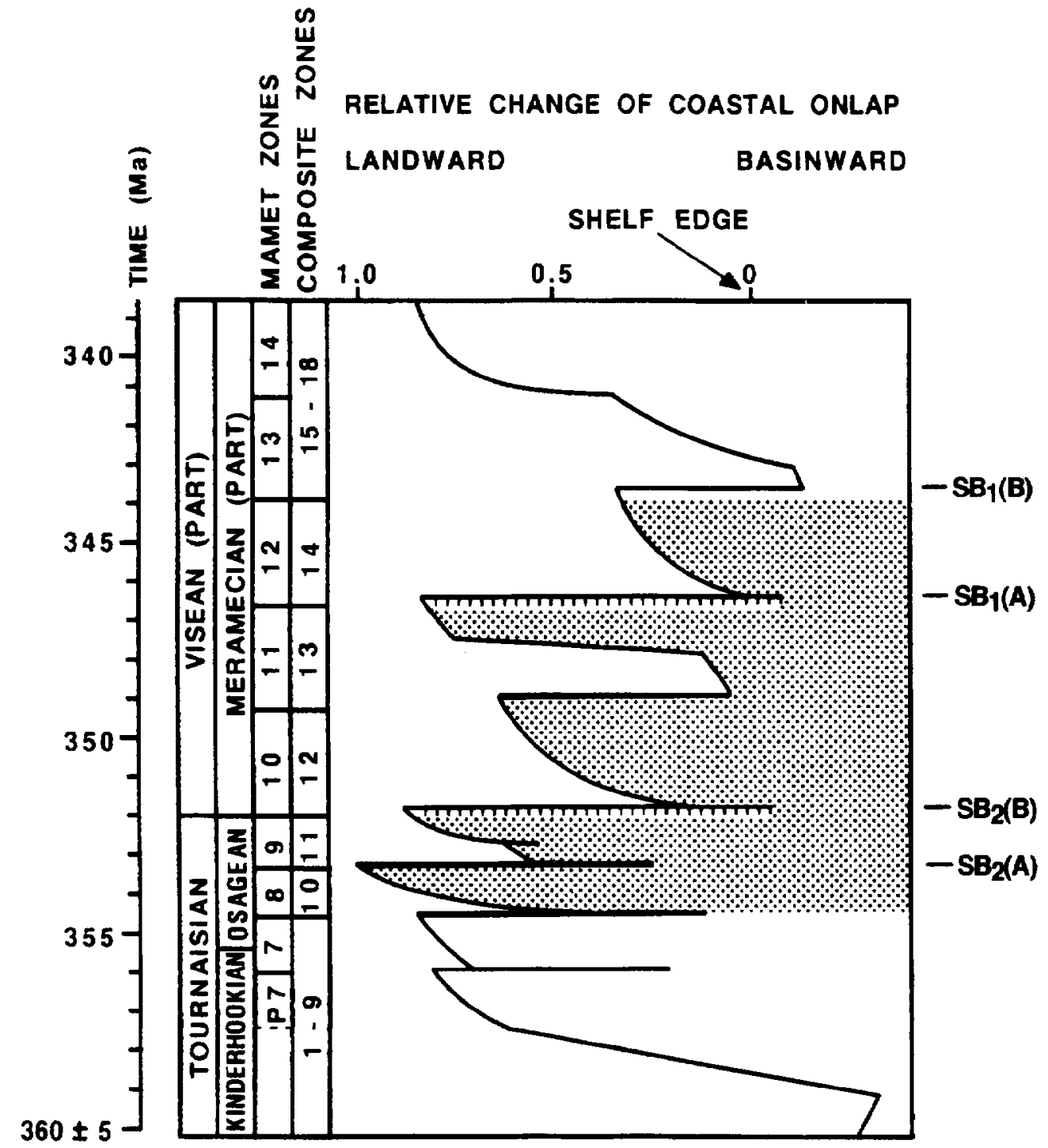

Figure 12. Coastal onlap-offlap curve of Ross and Ross (1987) modified to fit time scale of Sando (1985). Shaded portion corresponds with time of deposition of the Mission Canyon Formation and stratigraphic equivalents. Thin lines at sequence boundaries are "medium" sequence boundaries, heavy lines are "major" sequence boundaries, and hatched lines are "exposed lowstand surfaces" of Ross and Ross (1987). Correlative surfaces from this study are shown on the right (labels are the same as in Figure 10).

ilarities, while not conclusive, support our contention that parasequence sets formed in response to eustatic sea-level fluctuations.

Correlation of third-order sequence boundaries between southwestern Montana and the Williston basin is difficult because of poor biostratigraphic control and because a sequence stratigraphic analysis of the complete Mission Canyon and Charles formations has not been published. We can confidently correlate one third-order sequence boundary between these areas. In the central Williston basin, the composite zone $11 / 12$ boundary is located within $6 \mathrm{~m}$ of the K-1 (Fryburg) gamma-ray marker which separates the Sherwood and Mohall subintervals (Figure 13)
(Harris et al., 1966; Waters and Sando, 1987; Petty, 1988). Interestingly, the top of the Mohall subinterval is incised by channels that are backfilled by the Kisbey Sandstone (Witter, 1988). Therefore, $\mathrm{SB}_{2}(\mathrm{~B})$ probably correlates with the top of the Mohall subinterval in the Williston basin.

\section{Summary of Controls on Platform Development}

The Mission Canyon platform was deposited during relatively slow Osagean to middle Meramecian subsidence, which we interpret as a period of relative quiescence in the Antler thrust belt (cf. Figures 11, 12) (Dorobek et al., 1991a,b; Reid, 1991). Tectonic subsi- 


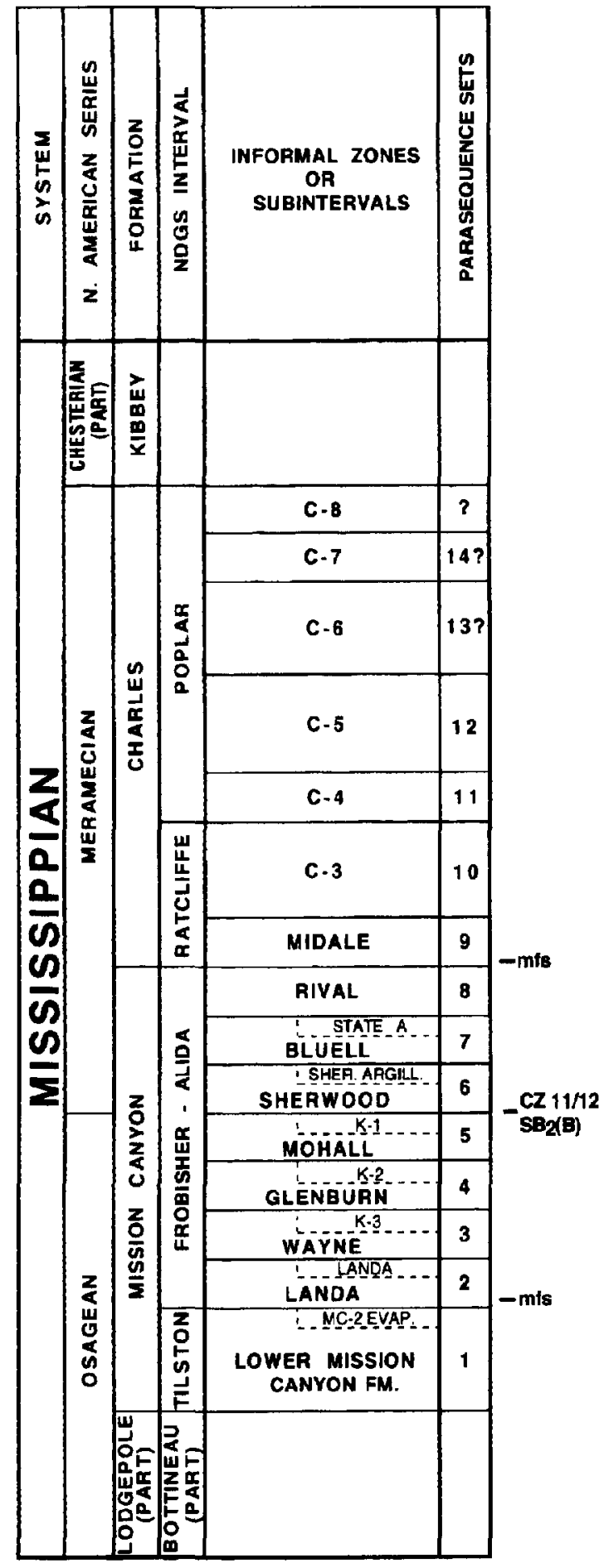

Figure 13. Correlation of parasequence sets ("sequences" of Reid, 1991; Reid and Dorobek, 1991) at locations BM and LK with informal subintervals of Harrison and Flood (1956) and Harris et al. (1966) from the central Williston basin. Numbers correspond to numbered parasequence sets on Figure 9 (also see figure 6 of Reid and Dorobek, 1991). CZ $11 / 12$ boundary (composite zone 11/12 boundary, Figure 3) is biostratigraphic datum. Correlative surfaces from Figure $\mathbf{1 0}$ are shown on the right.

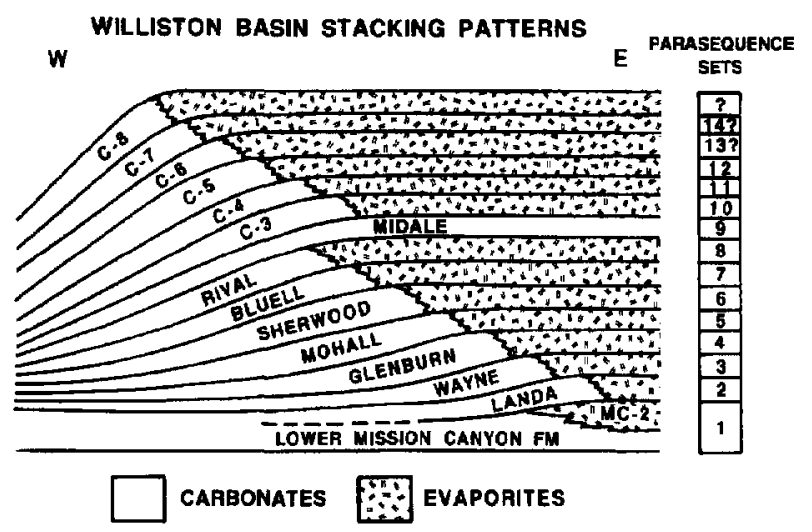

Figure 14. Schematic stratigraphic cross section illustrating large-scale stacking patterns of informal subintervals in the Williston basin (based on well $\log$ and core analyses of Harrison and Flood, 1956; Harris et al., 1966). Correlative parasequence sets (Figures 9, 13) are shown to the right of the cross section. Not to scale.

dence waned but generally outpaced gradual, second-order eustatic sea-level fall until middle to late Meramecian time. Relative tectonic quiescence during this time is suggested by a lack of coeval, coarsegrained, synorogenic siliciclastics in proximal Antler foredeep strata (Skipp and Mamet, 1970; Nilsen, 1977; Skipp et al., 1979; Dorobek et al., 1991a; Reid, 1991). Later, we discuss connotations of our sequence stratigraphic analysis on Antler foredeep subsidence history.

Third-order sequences within the Mission Canyon Formation and stratigraphic equivalents probably formed in response to third-order eustatic sea-level fluctuations (Figure 12) superimposed on the secondorder accommodation trend. Parasequence sets and parasequences may have formed in response to fourth- and fifth-order sea-level oscillations superimposed on third-order eustatic cycles.

Third- to fifth-order sea-level fluctuations may have been glacioeustatic. Late Paleozoic (Gondwanan) glaciation apparently began in the Early Carboniferous (Kinderhookian to Osagean) and culminated in the Permian-Carboniferous (Frakes and Crowell, 1969; Crowell, 1978; Caputo and Crowell, 1985). Caputo and Crowell (1985) suggested that Gondwana was never covered by a single large ice cap. Instead, smaller ice centers migrated across Gondwana from South America (Early Carboniferous) to eastern Australia and Antarctica (early Late Permian). Volume changes in this relatively small Early Carboniferous ice cap would have produced relatively low-amplitude sea-level fluctuations, perhaps on the order of 10 to, at most, a few tens of meters.

Relatively low-amplitude sea-level oscillations are consistent with a lack of evidence for deep submer- 
gence or drowning of the Mission Canyon ramp-interior. Fourth-order sea-level rises flooded regional(?) tidal flat and supratidal areas (i.e., tops of parasequence sets) to produce major marine flooding surfaces. However, the predominance of skeletal-ooid grainstones at the bases of ramp-interior parasequence sets suggests that the rates and magnitudes of sea-level rises generally were not great enough to cause drowning of the Mission Canyon platform nor to submerge the ramp-interior below fair-weather wave base.

\section{DEPOSITIONAL HISTORY}

Long-term evolution of the Mission Canyon platform is interpreted based on our regional sequence stratigraphic analysis and our present understanding of eustasy, regional tectonism, and relative sedimentation rates (inferred after Schlager, 1981). We cannot directly assess the influence of all types and scales of variables that appear to control development of carbonate ramps (e.g., Read et al., 1991). However, major processes described below may have operated across other broad, progradational carbonate ramps that developed adjacent to foreland basins.

\section{Tectonic Overprint on Sequence Development}

The reconstructed ramp to basin transect illustrates a progressive upward change in sequence boundary type during evolution of the Mission Canyon platform. Type 2 sequence boundaries (sensu Sarg, 1988) formed early in platform development, whereas type 1 sequence boundaries (sensu Sarg, 1988) dominated later platform development (Figure 10). Secondorder, eustatic sea-level fall must have outpaced tectonic subsidence during the later stages of platform deposition. This may reflect an increased rate of second-order eustatic sea-level fall during middle to late Meramecian time. However, we prefer to attribute this upward change in sequence boundary type to a gradual decrease in the rate of Antler foredeep subsidence. Slower flexural subsidence would have allowed third-order eustatic sea levels to fall well below the ramp margin, producing type 1 sequence boundaries. The Mission Canyon ramp margin is at or within typical flexural wavelengths for many foreland basins (cf. Jordan, 1981; Karner and Watts, 1983; Stockmal and Beaumont, 1987) based on existing palinspastic and paleogeographic reconstructions (Sando, 1976; Nilsen, 1977; Dover, 1980; Gutschick et al., 1980; Gutschick and Sandberg, 1983; Peterson, 1986).

Tectonic overprint of third-order eustatic sea-level cycles may explain differences between our interpretations of sequence boundary types and those of correlative surfaces on the Ross and Ross (1987) onlap-offlap curve (Figure 12). Type 2 sequence boundaries in the lower Mission Canyon platform correlate with sequence boundaries characterized as "major" and "exposed lowstand surfaces" on the
Ross and Ross (1987) curve. Conversely, the uppermost sequence boundary, which we interpret as type 1 , correlates with a "medium" sequence boundary on the Ross and Ross (1987) curve. This is consistent with a progressive decrease in the rate of flexural subsidence near the Mission Canyon ramp margin. Local tectonic influence also is suggested by the fact that $\mathrm{SB}_{2}(\mathrm{~B})$ has characteristics of a type 1 sequence boundary in the Williston basin (incised channels at the top of the Mohall subinterval; Witter, 1988) but appears to be a type 2 sequence boundary in southwestern Montana.

\section{Ramp Progradation and Development of Ramp-Margin Wedges}

The second-order decrease in accommodation forced the Mission Canyon platform to prograde into the distal Antler foredeep (Figure 10). In ramp-interior settings, the style of progradation is difficult to determine because of our inability to adequately define ramp-interior systems tracts. However, the predominance of progradational vertical stacking patterns of parasequences and largely aggradational vertical stacking of parasequence sets (Figures 8, 9, 10) suggests that ramp-interior sedimentation rates consistently kept pace with or exceeded rates of relative sea-level rises (characteristic of "keep-up" highstand and transgressive systems tracts of Sarg, 1988). Deposition of thick, apparently noncyclic grainstones at the bases of most ramp-interior parasequence sets is difficult to explain, but may reflect "extra" accommodation space generated by erosion or dominance of longer period (fourth-order?) and/or moderate amplitude (20-40 m ?) eustatic cycles (cf. Read et al., 1991).

The ability of the Mission Canyon ramp interior to accommodate large amounts of subtidal sediment may have affected progradation in outer ramp/slope settings. Conditions for optimal sediment production appear to have been largely confined to the ramp interior during most of third-order sequence development. Progradation into outer ramp/slope environments may not have begun until accommodation space across the ramp interior decreased during late highstands. In situ skeletal grainstone banks and/or thin sediment gravity flows derived from these banks may have prograded over outer ramp/slope lithofacies during late highstands and ensuing sea-level falls (Figure 10, note grainstones at the tops of outer ramp/slope parasequence sets). Major pulses of progradation into outer ramp/slope environments occurred when ramp-margin wedges (bounded below by sequence boundaries and above by transgressive surfaces) formed during third-order lowstands and early stages of succeeding sea-level rises (cf. Sarg, 1988).

Consistent upward variations in lithofacies and thicknesses of ramp-margin wedges support our interpretation that waning tectonic subsidence permitted third-order eustatic sea levels to fall 
progressively farther basinward as the Mission Canyon platform evolved (Figure 10). Both $\mathrm{SB}_{2}(\mathrm{~A})$ and $\mathrm{SB}_{2}(\mathrm{~B})$ are type 2 sequence boundaries. However, the ramp-margin wedge above $\mathrm{SB}_{2}(\mathrm{~A})$ is thinner than that deposited above $\mathrm{SB}_{2}(\mathrm{~B})$, and contains only minor peritidal lithofacies that prograded into ramp-margin to outer ramp areas (Figure 10, location $A$ ). The thicker ramp-margin wedge above $\mathrm{SB}_{2}(\mathrm{~B})$ represents a more significant basinward shift of peritidal lithofacies over the ramp margin (Figure 10, location A) and also marks the appearance of well-developed, stacked skeletal banks in former outer ramp/slope settings ( $\sim 30 \mathrm{~m}$ of massive skeletal grainstone, Figure 10, location LK).

The uppermost ramp-margin wedge is interpreted as a type 1 autochthonous carbonate wedge (sensu Sarg, 1988) that developed during major karstification of the Mission Canyon platform. This wedge is dominated by ramp-interior lithofacies that extend well beyond the former ramp margin (Figure 10). Third- to fifth-order sea-level fluctuations that controlled deposition of this wedge (and the overlying, areally limited highstand(?) systems tract) probably only affected former outer ramp/slope and rampmargin areas. However, onlapping strata above $\mathrm{SB}_{1}(\mathrm{~A})$ may have been eroded when $\mathrm{SB}_{1}(\mathrm{~B})$ formed. Exceptionally thick breccias at location $A$ suggest that part of this type 1 autochthonous wedge and much of the overlying highstand(?) systems tract were heavily karstified during development of $\mathrm{SB}_{1}(\mathrm{~B})$. The Mission Canyon platform probably remained emergent until the middle to late Meramecian (when the Kibbey Formation began to onlap the major karst surface) because it did not subside rapidly enough to allow flooding by relatively low-amplitude sea-level fluctuations.

\section{Maintenance of Ramp Profile}

The Mission Canyon platform appears to have maintained a ramplike profile throughout its development (Figure 10). Long-term maintenance of this ramplike profile may reflect a gradual basinward decrease in sedimentation rates across the platform to basin transition. However, the Antler foredeep was starved during deposition of the Mission Canyon platform (Sandberg, 1975; Nilsen, 1977; Skipp et al., 1979; Gutschick and Sandberg, 1983), which suggests that the difference between ramp-interior and basinal sedimentation rates may have been sufficient to generate a more pronounced break in slope across the ramp margin. We suggest that the upward change in sequence boundary type (and related changes in ramp-margin wedges) caused long-term maintenance of a ramplike profile. Basinward shifts in the locus of optimum sediment production and accumulation during each subaerial exposure of the ramp interior tended to "even-out" ramp-margin slopes. Had these shifts not occurred, the Mission Canyon platform probable would have developed characteristics more like those of a rimmed shelf.

\section{SUMMARY AND CONCLUSIONS}

The Lower Mississippian Mission Canyon Formation and stratigraphic equivalents in Montana and Idaho were deposited on a progradational carbonate ramp that developed on the foreland side of the Antler foredeep. In individual outcrops, these strata consist of prominent, stacked parasequence sets (18-62 $\mathrm{m}$ thick). These shallowing-upward units are comprised of smaller scale (1-10 $\mathrm{m}$ thick) parasequences in ramp-interior settings; however, parasequences have not been recognized in outer ramp/slope parasequence sets. Parasequence sets are our primary units for regional sequence stratigraphic analysis.

Lateral lithofacies relationships across the deformed ramp to basin transition were reconstructed by biostratigraphically and lithostratigraphically correlating six key measured sections from a larger regional database. Depositional sequences and systems tracts within sequences were identified from characteristics of bounding surfaces, stacking patterns of parasequences and parasequence sets, and lateral lithofacies relationships.

Third-order sequence boundaries show a progressive upward change in type; type 2 sequence boundaries formed early in ramp development, and type 1 sequence boundaries formed during the later stages of ramp deposition. Associated ramp-margin wedges become thicker and consist of progressively larger proportions of peritidal lithofacies toward the top of the Mission Canyon Formation and stratigraphic equivalents. Based primarily on quantitative subsidence analysis and comparisons with published onlap-offlap curves, we interpret this upward change in sequence boundary type (and related changes in ramp-margin wedges) as a depositional response to gradually decreasing Antler foredeep subsidence concurrent with second-order sea-level fall. Gradually waning flexural subsidence probably allowed higher order eustatic sea levels (superimposed on secondorder eustasy) to fall progressively farther basinward as the Mission Canyon platform evolved.

The documented long-term decrease in accommodation caused progradation of the Mission Canyon platform and helped maintain a ramplike profile across the platform to basin transition. The Mission Canyon ramp interior was able to accommodate large amounts of subtidal sediment, which may have affected progradation into outer ramp/slope settings. Conditions for optimal sediment production may have been primarily confined to the ramp interior during most of third-order sequence development. Progradation into outer ramp/slope environments may not have begun until accommodation space decreased during late highstands. Major pulses of progradation into outer ramp/slope environments occurred during third-order lowstands and early stages of succeeding sea-level rises when ramp-margin wedges formed. Ramp-margin wedges tended to "even out" ramp-margin slopes and maintained a 
ramplike profile across the platform to basin transition. The long-term decrease in accommodation prevented the Mission Canyon platform from developing characteristics more like those of a rimmed shelf.

\section{ACKNOWLEDGMENTS}

This chapter is based on the senior author's dissertation research conducted at Texas A\&M University. Research was supported by U.S. Department of Energy Grant DE-FG05-87ER13767, Basic Energy Sciences to S. Dorobek. Such support does not constitute an endorsement by DOE of the views expressed in this paper. Acknowledgment also is made to the Donors of The Petroleum Research Fund, administered by the American Chemical Society, for partial support of this research (Grant \#19519-G2 to S. Dorobek). Additional support was provided by Geological Society of America Grants-in-Aid to S. Reid. Field assistance was provided by T. Smith and J. Harris. Field data from location $\mathrm{T}$ was provided by $\mathrm{T}$. Smith. W. Sando identified corals collected by the senior author, allowed examination of unpublished data, and provided comments about stratigraphy that helped constrain interpretations. A. Harris kindly identified conodonts in samples collected at location LK by the senior author. Correlations with the Williston basin were better constrained by discussions with D. Witter. This chapter was improved by insightful reviews by R. Loucks and S. Greenlee. Special acknowledgment is made to J. Markello for his painstaking review of an earlier version of this paper. His suggestions regarding identification of third-order sequences on our regional cross section were invaluable. However, omissions or unintentional misrepresentations of reviewers ${ }^{\prime}$ or contributors suggestions is our responsibility.

\section{REFERENCES CITED}

Ahr, W.M., 1973, The carbonate ramp: An alternative to the shelf model: Transactions, Gulf Coast Association of Geological Societies, v. 23, p. 221225.

Ball, M.M., 1967, Carbonate sand bodies of Florida and the Bahamas: Journal of Sedimentary Petrology, v. 37, p. 556-591.

Caputo, M.V., and J.C. Crowell, 1985, Migration of glacial centers across Gondwana during Paleozoic Era: Geological Society of America Bulletin, v. 96, p. 1020-1036.

Cook, H.E., and P. Enos, 1977, Deep-Water Carbonate Environments: SEPM Special Publication No. 25, $336 \mathrm{p}$.

Cook, H.E., and M.E. Taylor, 1977, Comparison of continental slope and shelf environments in the Upper Cambrian and lowest Ordovician of Nevada, in Cook, H.E., and P. Enos, 1977, eds., Deep-Water Carbonate Environments: SEPM Special Publication No. 25, p. 51-81.
Crowell, J.C., 1978, Gondwanan glaciation, cyclothems, continental positioning, and climate change: American Journal of Science, v. 278, p. 1345-1372.

Davies, G.R., 1977, Turbidites, debris sheets, and truncation structures in Upper Paleozoic deepwater carbonates of the Sverdrup Basin, Arctic Archipelago, in Cook, H.E., and P. Enos, eds., Deep-Water Carbonate Environments: SEPM Special Publication No. 25, p. 221-247.

Dorobek, S.L., and J.F. Read, 1986, Sedimentology and basin evolution of the Siluro-Devonian Helderberg Group, central Appalachians: Journal of Sedimentary Petrology, v. 56, p. 601-613.

Dorobek, S.L., S.K. Reid, and M. Elrick, 1991a, Antler foreland stratigraphy of Montana and Idaho: The stratigraphic record of eustatic fluctuations and episodic tectonic events, in Cooper, J.D., and C.H. Stevens, eds., Paleozoic Paleogeography of the Western United States-II: SEPM, Pacific Section, v. 67, p. $487-507$.

Dorobek, S.L., S.K. Reid, M. Elrick, G.C. Bond, and M.A. Kominz, 1991b, Subsidence across the Antler foreland of Montana and Idaho: Tectonic versus eustatic effects, in Franseen, E.K., W.L. Watney, C.G.St.C. Kendall, and W. Ross, eds., Sedimentary Modeling: Computer Simulation and Methods for Improved Parameter Definition: Kansas Geological Society Bulletin 233, p. 231-251.

Dover, J.H., 1980, Status of the Antler orogeny in central Idaho-Clarification and constraints from the Pioneer Mountains, in Fouch, T.D., and E.R. Magathan, eds., Paleozoic Paleogeography of the West-central United States: SEPM, Rocky Mountain Section, Rocky Mountains Paleogeography Symposium 1, p. 371-386.

Esteban, M., 1976, Vadose pisolite and caliche: AAPG Bulletin, v. 60 , p. 2048-2057.

Esteban, M., and C.F. Klappa, 1983, Subaerial exposure, in Scholle, P.A., D.G. Bebout, and C.H. Moore, eds., Carbonate Depositional Environments: AAPG Memoir 33, p. 1-54.

Fischer, A.G., 1964, The Lofer cyclothems of the Alpine Triassic: Kansas Geological Survey Bulletin, v. 169, p. 107-149.

Frakes, L.A., and J.C. Crowell, 1969, Late Paleozoic glaciation-Part I, South America: Geological Society of America Bulletin, v. 80, p. 1007-1042.

Franseen, E.K., T.E. Fekete, and L.C. Pray, 1989, Evolution and destruction of a carbonate bank at the shelf margin: Grayburg Formation (Permian), Western Escarpment, Guadalupe Mountains, Texas, in Crevello, P.D., J.L. Wilson, J.F. Sarg, and J.F. Read, eds., Controls on Carbonate Platform and Basin Development: SEPM Special Publication No. 44, p. 289-304.

Goldhammer, R.K., P.A. Dunn, and L.A. Hardie, 1987, High frequency glacio-eustatic sealevel oscillations with Milankovitch characteristics recorded in Middle Triassic platform carbonates in northern Italy: American Journal of Science, v. 287, p. 853-892. 
Goldhammer, R.K., P.A. Dunn, and L.A. Hardie, 1990, Depositional cycles, composite sea level changes, cycle stacking patterns, and the hierarchy of stratigraphic forcing-examples from platform carbonates of the Alpine Triassic: Geological Society of America Bulletin, v. 102, p. 535-562.

Goldhammer, R.K., E.J. Oswald, and P.A. Dunn, 1991, Hierarchy of stratigraphic forcing: Example from Middle Pennsylvanian shelf carbonates of the Paradox basin, in Franseen, E.K., W.L. Watney, C.G.St.C. Kendall, and W. Ross, eds., Sedimentary Modeling: Computer Simulation and Methods for Improved Parameter Definition: Kansas Geological Society Bulletin 233, p. 362-413.

Gutschick, R.C., and C.A. Sandberg, 1983, Mississippian continental margins of the conterminous United States, in Stanley, D.J., and G.T. Moore, eds., The Shelfbreak: Critical Interface on Continental Margins: SEPM Special Publication No. 33, p. 79-96.

Gutschick, R.C., C.A. Sandberg, and W.J. Sando, 1980, Mississippian shelf margin and carbonate platform from Montana to Nevada, in Fouch, T.D., and E.R. Magathan, eds., Paleozoic Paleogeography of the West-central United States: SEPM, Rocky Mountain Section, Rocky Mountain Paleogeography Symposium 1, p. 111-128.

Haq, B.U., J. Hardenbol, and P.R. Vail, 1988, Mesozoic and Cenozoic chronostratigraphy and eustatic cycles, in Wilgus, C.K., B.S. Hastings, C.G.St.C. Kendall, H.W. Posamentier, C.A. Ross, and J.C. Van Wagoner, eds., Sea Level Changes: An Integrated Approach: SEPM Special Publication No. 42, p. 71-108.

Harris, S.H., C.B. Land, and J.H. McKeever, 1966, Relation of Mission Canyon stratigraphy to oil production in north-central North Dakota: AAPG Bulletin, v. 50, p. 2269-2276.

Harrison, R.L., and A.L. Flood, 1956, Mississippian correlation in the international boundary areas, in First International Williston Basin Symposium: North Dakota and Saskatchewan Geological Societies, Conrad Publishing, Bismark, North Dakota, p. 36-51.

Heckel, P.H., 1974, Carbonate buildups in the geologic record: A review, in Laporte, L.F., ed., Reefs in Time and Space: SEPM Special Publication No. 18, p. 90-155.

Hendricks, M.L., 1988, Shallowing-upward cyclic carbonate reservoirs in the lower Ratcliff interval (Mississippian), Williams and McKenzie Counties, North Dakota, in Goolsby, S.M., and M.W. Longman, eds., Occurrence and Petrophysical Properties of Carbonate Reservoirs in the Rocky Mountain Region: Rocky Mountain Association of Geologists, p. 371-380.

Hine, A.C., 1977, Lily Bank, Bahamas: History of an active oolite sand shoal: Journal of Sedimentary Petrology, v. 47, p. 1554-1581.

Huh, O.K., 1967, The Mississippian System across the Wasatch Line east central Idaho, extreme south- western Montana, in Centennial Basin of Southwest Montana-Guidebook, 18th Annual Field Conference: Montana Geological Society, Billings, Montana, p. 31-62.

Huh, O.K., 1968, Mississippian stratigraphy and sedimentology, across the Wasatch Line, east-central Idaho and extreme southwestern Montana, Ph.D. dissertation: The Pennsylvania State University, University Park, 176 p.

James, N.P., 1984, Reefs, in Walker, R.G., ed., Facies Models: Geoscience Canada, Reprint Series 1, p. 229-244.

Jordan, T.E., 1981, Thrust loads and foreland basin development, Cretaceous, western United States: AAPG Bulletin, v. 65, p. 2506-2520.

Karner, G.D., and A.B. Watts, 1983, Gravity anomalies and flexure of the lithosphere at mountain ranges: Journal of Geophysical Research, v. 88, p. 10449-10477.

Kendall, C.G.St.C., and P.A.D.E. Skipwith, 1969, Holocene shallow-water carbonate and evaporite sediments of Khor al Bazam, Abu Dhabi, southwest Persian Gulf: AAPG Bulletin, v. 53, p. 841869.

Kinsman, D.J.J., 1964, The recent carbonate sediments near Halat el Bahrani, Trucial Coast, Persian Gulf, in Deltaic and Shallow Marine DepositsDevelopments in Sedimentology, v. 1: Elsevier, Amsterdam, p. 185-192.

Kreisa, R.D., 1981, Storm generated sedimentary structures in subtidal marine facies with examples from the Middle and Upper Ordovician of southwestern Virginia: Journal of Sedimentary Petrology, v. 51, p. 823-848.

Laporte, L.F., 1969, Recognition of a transgressive carbonate sequence within an epeiric sea; Helderberg Group (Lower Devonian) of New York State, in Friedman, G.M., ed., Depositional Environments in Carbonate Rocks: SEPM Special Publication No. 14, p. 98-119.

Logan, B.W., 1974, Inventory of diagenesis in Holocene-Recent carbonate sediments, Shark Bay, Western Australia, in Logan, B.W., J.F. Read, G.M. Hagen, P. Hoffman, R.G. Brown, P.J. Woods, and C.D. Gebelein, eds., Evolution and Diagenesis of Quaternary Carbonate Sequences, Shark Bay, Western Australia: AAPG Memoir 22, p. 195249.

Logan, B.W., P. Hoffman, and C.D. Gebelein, 1974, Algal structures, cryptalgal fabrics, and structures, Hamblin Pool, Western Australia, in Logan, B.W., J.F. Read, G.M. Hagen, P. Hoffman, R.G. Brown, P.J. Woods, and C.D. Gebelein, eds., Evolution and Diagenesis of Quaternary Carbonate Sequences, Shark Bay, Western Australia: AAPG Memoir 22, p. 140-194.

Lowe, D.R., 1979, Sediment gravity flows: Their classification and some problems of application to natural flows and deposits, in Doyle, L.J., and O.H. Pilkey, eds., Geology of Continental Slopes: SEPM Special Publication No. 27, p. 75-82. 
Mazzullo, S.J., and B.A. Birdwell, 1989, Syngenetic formation of grainstones and pisolites from fenestral carbonates in peritidal settings: Journal of Sedimentary Petrology, v. 59, p. 605-611.

Middleton, G.V., 1961, Evaporite solution breccias from the Mississippian of southwest Montana: Journal of Sedimentary Petrology, v. 31, p. 189-195.

Middleton, G.V., and M.A. Hampton, 1976, Subaqueous sediment transport and deposition by sediment gravity flows, in Stanley, D.J., and D.J.P. Swift, eds., Marine Sediment Transport and Environmental Management: John Wiley \& Sons, New York, p. 197-218.

Mitchum, R.M., Jr., 1977, Seismic stratigraphy and global changes of sea level, Part 2: Glossary of terms used in seismic stratigraphy, in Payton, C.E., ed., Seismic Stratigraphy-Application to Hydrocarbon Exploration: AAPG Memoir 26, p. 205-212.

Mitchum, R.M., Jr., P.R. Vail, and S. Thompson III, 1977, Seismic stratigraphy and global changes of sea level, Part 2: The depositional sequence as a basic unit for stratigraphic analysis, in Payton, C.E., ed., Seismic Stratigraphy-Application to Hydrocarbon Exploration: AAPG Memoir 26, p. 53-62.

Nichols, K.M., 1980, Depositional and diagenetic history of porous dolomitized grainstones at the top of the Madison Group, Disturbed Belt, Montana, in Fouch, T.D., and E.R. Magathan, eds., Paleozoic Paleogeography of the West-central United States: SEPM, Rocky Mountain Section, Rocky Mountain Paleogeography Symposium 1, p. 163-173.

Nilsen, T.H., 1977, Paleogeography of Mississippian turbidites in south-central Idaho, in Stewart, J.H., C.H. Stevens, and A.E. Fritsche, eds., Paleozoic Paleogeography of the West-central United States: SEPM, Pacific Section, Pacific Coast Paleogeography Symposium 1, p. 275-299.

Peterson, J.A., 1986, General stratigraphy and regional paleotectonics of the western Montana overthrust belt, in Peterson, J.A., ed., Paleotectonics and Sedimentation in the Rocky Mountain Region, United States: AAPG Memoir 41, p. 57-86.

Petty, D.M., 1988, Depositional facies, textural characteristics, and reservoir properties of dolomites in Frobisher-Alida interval in southwest North Dakota: AAPG Bulletin, v. 72, p. 1229-1253.

Purser, B.H., 1973, The Persian Gulf-Holocene carbonate sedimentation and diagenesis in a shallow water epicontinental sea: Springer-Verlag, Berlin, $471 \mathrm{p}$.

Read, J.F., 1974, Calcrete deposits and Quaternary sediments, Edel Province, Shark Bay, Western Australia, in Logan, B.W., J.F. Read, G.M. Hagen, P. Hoffman, R.G. Brown, P.J. Woods, and C.D. Gebelein, eds., Evolution and Diagenesis of Quaternary Carbonate Sequences, Shark Bay, Western Australia: AAPG Memoir 22, p. 250-282.

Read, J.F., 1985, Carbonate platform facies models: AAPG Bulletin, v. 69, p. 1-21.
Read, J.F., D. Osleger, and M. Elrick, 1991, Twodimensional modeling of carbonate ramp sequences and component cycles, in Franseen, E.K., W.L. Watney, C.G.St.C. Kendall, and W. Ross, eds., Sedimentary Modeling: Computer Simulation and Methods for Improved Parameter Definition: Kansas Geological Society Bulletin 233, p. 473-488.

Reid, S.K., 1991, Evolution of the Early Mississippian Mission Canyon platform and Antler foredeep, Montana and Idaho, Ph.D. dissertation: Texas A\&M University, College Station, Texas, $105 \mathrm{p}$.

Reid, S.K., and S.L. Dorobek, 1991, Controls on development of third- and fourth-order depositional sequences in the Lower Mississippian Mission Canyon Formation and stratigraphic equivalents, Idaho and Montana, in Cooper, J.D. and C.H. Stevens, eds., Paleozoic Paleogeography of the Western United States-II: SEPM, Pacific Section, v. 67, p. $527-541$.

Rhoads, D.C., 1975, The paleoecological and environmental significance of trace fossils, in Frey, R.W., ed., The Study of Trace Fossils: Springer-Verlag, New York, p. 147-160.

Roberts, A.E., 1966, Stratigraphy of Madison Group near Livingston, Montana, and discussion of karst and solution-breccia features: U.S. Geological Survey Professional Paper 526-B, p. B1-B23.

Rose, P.R., 1976, Mississippian carbonate shelf margins, western United States: U.S. Geological Survey Journal of Research, v. 4, p. 449-466.

Ross, C.A., and J.P. Ross, 1987, Late Paleozoic sea levels and depositional sequences, in Ross, C.A., and D. Haman, eds., Timing and Depositional History of Eustatic Sequences: Constraints on Seismic Stratigraphy: Cushman Foundation for Foraminiferal Research, Special Publication No. 24, p. 137-149.

Ross, W.C., 1991, Cyclic stratigraphy, sequence stratigraphy, and stratigraphic modeling from 1964 to 1989: Twenty-five years of progress?, in Franseen, E.K., W.L. Watney, C.G.St.C. Kendall, and W. Ross, eds., Sedimentary Modeling: Computer Simulation and Methods for Improved Parameter Definition: Kansas Geological Society Bulletin 233, p. 3-8.

Sandberg, C.A., 1975, McGowan Creek Formation, new name for Lower Mississippian flysch sequence in east-central Idaho: U.S. Geological Survey Bulletin, v. 1405-E, 11 p.

Sandberg, C.A., R.C. Gutschick, J.G. Johnson, F.G. Poole, and W.J. Sando, 1983, Middle Devonian to Late Mississippian geologic history of the Overthrust Belt region, western United States: Rocky Mountain Association of Geologists, Geologic Studies of the Cordilleran Thrust Belt, v. 2, p. 691-719.

Sandberg, C.A., and Poole, F.G., 1977, Conodont biostratigraphy and depositional complexes of Upper Devonian cratonic-platform and continental shelf rocks in the western United States, in Murphy, 
M.A., W.B.N. Berry, and C.A. Sandberg, eds., Western North America; Devonian: Campus Museum Contributions 4, California University, Riverside, p. 144-182.

Sando, W.J., 1972, Madison Group (Mississippian) and Amsden Formation (Mississippian and Pennsylvanian) in the Beartooth Mountains, northern Wyoming and southern Montana: Montana Geological Society, 21st Annual Field Conference, p. 57-63.

Sando, W.J., 1974, Ancient solution phenomena in the Madison Limestone (Mississippian) in north-central Wyoming: U.S. Geological Survey Journal of Research, v. 2, p. 133-141.

Sando, W.J., 1976, Mississippian history of the northern Rocky Mountains Region: U.S. Geological Survey Journal of Research, v. 4, p. 317-338.

Sando, W.J., 1985, Revised Mississippian time scale, western interior region, conterminous United States: U.S. Geological Survey Bulletin, v. 1605-A, p. A15-A26.

Sando, W.J., 1988, Madison Limestone (Mississippian) paleokarst: A geologic synthesis, in James, N.P., and P.W. Choquette, eds., Paleokarst: SpringerVerlag, New York, p. 256-277.

Sando, W.J., and E.W. Bamber, 1985, Coral zonation of the Mississippian System in the western interior province of North America: U.S. Geological Survey Professional Paper 1334, $61 \mathrm{p}$.

Sando, W.J., and J.T. Dutro, Jr., 1960, Stratigraphy and coral zonation of the Madison Group and Brazer Dolomite in northeastern Utah, western Wyoming, and southwestern Montana: Wyoming Geological Association Guidebook, Fifteenth Annual Field Conference, p. 117-126.

Sando, W.J., and J.T. Dutro, Jr., 1974, Type sections of the Madison Group (Mississippian) and its subdivisions in Montana: U.S. Geological Survey Professional Paper 842, $22 \mathrm{p}$.

Sando, W.J., and J.T. Dutro, Jr., 1980, Paleontology and correlation of the Madison Group at Baldy Mountain, in Hadley, J.B., Geology of the Varney and Cameron Quadrangles, Madison County, Montana: U.S. Geological Survey Bulletin 1459, p. 33-46.

Sando, W.J., B.L. Mamet, and J.T. Dutro, Jr., 1969, Carboniferous megafaunal and microfaunal zonation in the Northern Cordillera of the United States: U.S. Geological Survey Professional Paper 613-E, $29 \mathrm{p}$.

Sando, W.J., C.A. Sandberg, and W.J. Perry, Jr., 1985, Revision of Mississippian stratigraphy, Northern Tendoy Mountains, southwest Montana, in Sando, W.J., ed., Mississippian and Pennsylvanian Stratigraphy in Southwest Montana and Adjacent Idaho: U.S. Geological Survey Bulletin, v. 1656, p. A1-A10.

Sarg, J.F., 1988, Carbonate sequence stratigraphy, in Wilgus, C.K., B.S. Hastings, C.G.St.C. Kendall, H.W. Posamentier, C.A. Ross, and J.C. Van Wagoner, eds., Sea Level Changes: An Integrated
Approach: SEPM Special Publication No. 42, p. 155-181.

Schlager, W., 1981, The paradox of drowned reefs and carbonate platforms: Geological Society of America Bulletin, v. 92, p. 197-211.

Scholle, P.A., and Kinsman, D.J.J., 1974, Aragonitic and high-Mg calcite caliche from the Persian Gulf-a modern analog for the Permian of Texas and New Mexico: Journal of Sedimentary Petrology, v. 44, p. 904-916.

Seilacher, A., 1967, Bathymetry of trace fossils: Marine Geology, v. 5, p. 413-428.

Shinn, E.A., 1983, Tidal flat environment, in Scholle, P.A., D.G. Bebout, and C.H. Moore, eds., Carbonate Depositional Environments: AAPG Memoir 33, p. 171-210.

Skipp, B., and B.L. Mamet, 1970, Stratigraphic micropaleontology of the type locality of the White Knob Limestone (Mississippian), Custer County, Idaho: U.S. Geological Survey Professional Paper 700-B, p. B118-B123.

Skipp, B., W.J. Sando, and W.E. Hall, 1979, The Mississippian and Pennsylvanian (Carboniferous) Systems in the United States-Idaho: U.S. Geological Survey Professional Paper 1110-AA, 42 p.

Sloss, L.L., 1963, Sequences in the cratonic interior of North America: Geological Society of America Bulletin, v. 74, p. 93-113.

Sloss, L.L., W.C. Krumbein, and E.C. Dapples, 1949, Integrated facies analysis, in Longwell, C.R., chair, Sedimentary Facies in Geologic History: Geological Society of America Memoir 39, p. 91-124.

Stockmal, G.S., and C. Beaumont, 1987, Geodynamic models of convergent margin tectonics: The southern Canadian Cordillera and the Swiss Alps, in Beaumont, C., and A.J. Tankard, eds., Sedimentary Basins and Basin Forming Mechanisms: Canadian Society of Petroleum Geologists, Memoir 12, p. 393-411.

Vail, P.R., R.M. Mitchum, Jr., S. Thompson III, 1977a, Seismic stratigraphy and global changes of sea level, Part 4: Global cycles and relative changes of sea level, in Payton, C.E., ed., Seismic Stratigraphy-Application to Hydrocarbon Exploration: AAPG Memoir 26, p. 49-212.

Vail, P.R., R.G. Todd, and J.B. Sangree, 1977b, Seismic stratigraphy and global changes of sea level, Part 5: Chronostratigraphic significance of seismic reflections, in Payton, C.E., ed., Seismic StratigraphyApplication to Hydrocarbon Exploration: AAPG Memoir 26, p. 99-116.

Van Wagoner, J.C., H.W. Posamentier, R.M. Mitchum, P.R. Vail, J.F. Sarg, T.S. Loutit, and J. Hardenbol, 1988, An overview of the fundamentals of sequence stratigraphy and key definitions, in Wilgus, C.K., B.S. Hastings, C.G.St.C. Kendall, H.W. Posamentier, C.A. Ross, and J.C. Van Wagoner, eds., Sea Level Changes: An Integrated Approach: SEPM Special Publication No. 42, p. 39-45.

Waters, D.L., and Sando, W.J., 1987, Coral zonules: New tools for petroleum exploration in the 
Mission Canyon Limestone and Charles Formation, Williston Basin, North Dakota: Rocky Mountain Association of Geologists, 1987 Symposium, p. 193-208.

Wilgus, C.K., Hastings, B.S., Kendall, C.G.St.C., Posamentier, H.W., Ross, C.A., and Van Wagoner, J.C., 1988, Sea Level Changes: An Integrated Approach: SEPM Special Publication No. 42, 407 p. Wilson, J.L., 1969, Microfacies and sedimentary struc- tures in "deeper water" lime mudstones: SEPM Special Publication No. 14, p. 4-19.

Wilson, J.L., 1975, Carbonate facies in geologic history: Springer-Verlag, New York, $471 \mathrm{p}$.

Witter, D.N., 1988, Stratal architecture and volumetric distribution of facies tracts, Upper Mission Canyon Formation (Mississippian), Williston Basin, North Dakota, M.S. thesis: Colorado School of Mines, Golden, Colorado, $180 \mathrm{p}$. 